\title{
Small Molecule NF-кB Pathway Inhibitors in Clinic
}

\author{
Venkataramanan Ramadass ${ }^{1, *}$, Thamilselvan Vaiyapuri ${ }^{1, *}$ and Vinay Tergaonkar ${ }^{1,2}$ \\ 1 Institute of Molecular and Cell Biology (IMCB), Singapore 138673, Singapore; vinayt@imcb.a-star.edu.sg \\ 2 Department of Pathology, NUS, Singapore 117597, Singapore \\ * Correspondence: venkataramananr@imcb.a-star.edu.sg (V.R.); thamilsv@imcb.a-star.edu.sg (T.V.)
}

Received: 12 June 2020; Accepted: 14 July 2020; Published: 21 July 2020

\begin{abstract}
Nuclear factor kappa B (NF- $\mathrm{kB}$ ) signaling is implicated in all major human chronic diseases, with its role in transcription of hundreds of gene well established in the literature. This has propelled research into targeting the NF- $\mathrm{KB}$ pathways for modulating expression of those genes and the diseases mediated by them. In-spite of the critical, but often promiscuous role played by this pathway and the inhibition causing adverse drug reaction, currently many biologics, macromolecules, and small molecules that modulate this pathway are in the market or in clinical trials. Furthermore, many marketed drugs that were later found to also have NF- $\mathrm{kB}$ targeting activity were repurposed for new therapeutic interventions. Despite the rising importance of biologics in drug discovery, small molecules got around 76\% of US-FDA (Food and Drug Administration-US) approval in the last decade. This encouraged us to review information regarding clinically relevant small molecule inhibitors of the NF-KB pathway from cell surface receptor stimulation to nuclear signaling. We have also highlighted the underexplored targets in this pathway that have potential to succeed in clinic.
\end{abstract}

Keywords: NF-kB pathway; small molecules; clinical trials; anti-cancer; anti-inflammatory; autoimmune disease

\section{Introduction}

Nuclear factor kappa B (NF-kB) signaling has been well studied for more than three decades from the first report by Sen et al. [1] in 1986. It is implicated in both normal physiology [2,3] and in the development of a multitude of diseases [4] ranging from inflammation [5,6], cancer [7-9] to autoimmune disorders $[10,11]$. Thus, it is not surprising that many researcher groups are actively pursuing efforts to modulate this pathway for therapeutic intervention. Despite the vast knowledge for this pathway and several compounds in preclinical stage still there is a dearth of clinically proven molecules. As a case in point, Gilmore et.al. [12] enlisted 785 inhibitors of NF-kB signaling in 2006 but only few of them did even reach clinical trials. In this review, we aim to analyze the small molecule inhibitors of NF- $\mathrm{kB}$ pathways that were taken into clinical trials.

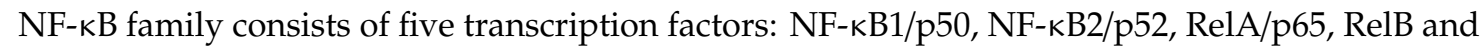
$\mathrm{c}-$ Rel that homodimerize or heterodimerize to $15 \mathrm{NF}-\mathrm{kB}$ complexes [13]. These are mainly found in the cytoplasm of resting cells and upon activation they translocate to the nucleus for transcription which in-turn leads to direct or indirect activation or repression of hundreds of genes. Notwithstanding their ubiquitous nature, they show high contextual diversity for transcription based on the tissue type and specific biological circumstances [14].

The NF- $\mathrm{kB}$ pathway can be triggered by diverse stimuli that includes inflammatory cytokines, immune signals and antigens, microbial products and stress signals [15]. Upon stimulation, either the canonical or the non-canonical pathway (Figure 1) is activated, depending on the type of Inhibitor of $\kappa \mathrm{B}(\mathrm{I} \kappa \mathrm{B})$ protein or IKB kinase (IKK) complex involved. The biology of this signaling cascade is well reviewed in the literature [16,17]. On stimulation of the receptor, canonical pathway mediated through 
adapter proteins and kinases, activates IKK complex that comprises of IKK $\alpha / \beta / \gamma$. Polyubiquitination and site-specific phosphorylation subsequently lead to proteasomal degradation of IKB protein and release of NF- $\mathrm{kB}$ dimers for translocation to the nucleus. Furthermore, the pathway mediated by NF-KB1/p50, also involves partial degradation of p105 to p50. Non-canonical pathway [18,19], on stimulation recruit tumor necrosis factor (TNF) receptor-associated factor (TRAF) and cellular inhibitor of apoptosis (c-IAP) as TRAF2/TRAF3/c-IAP1/2 complex. NF-kB-inducing kinase (NIK), that is constitutively bound to the complex, on activation dissociates, gets stabilized and phosphorylate IKK $\alpha$ homodimer. This leads to partial degradation of p100 to p52 and the RelB/p52 heterodimer translocate to nucleus for further transcription [20].

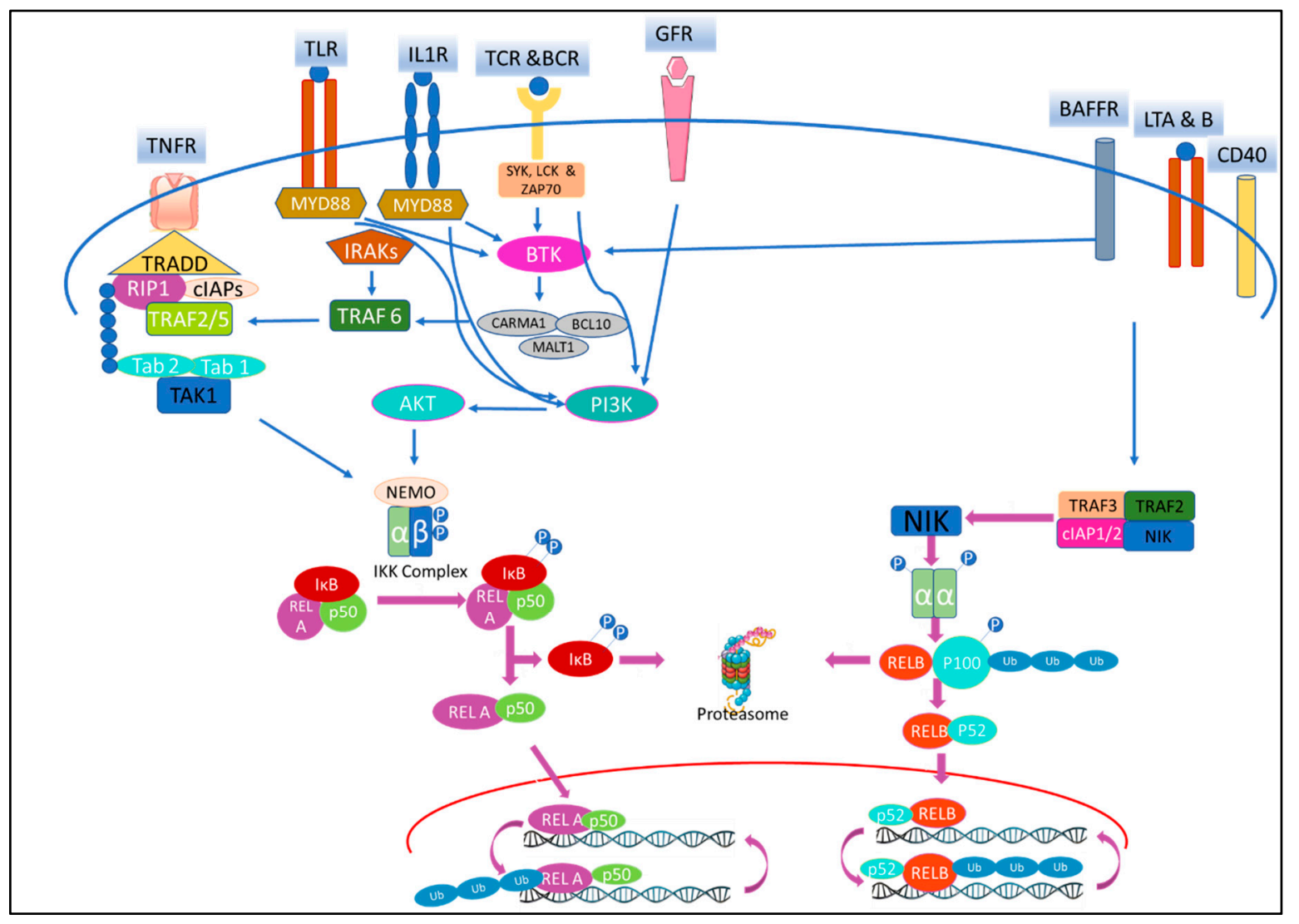

Figure 1. Schematic diagram of the canonical and non-canonical Nuclear factor kappa B (NF- $\mathrm{B}$ ) signaling pathways. Canonical NF- $\mathrm{kB}$ signaling cascade is initiated at the cell membrane through tumor necrosis factor $-\alpha$ receptor (TNFR), interleukin1 receptor (IL1R), toll-like receptor (TLR), T-cell receptors (TCR), B-cell receptors (BCR), and growth factor receptors (GFR) while the non-canonical pathway can be stimulated via receptors such as lymphotoxin $\alpha$ and $\beta$ (LTA and B), cluster of differentiation 40 (CD40) and B-cell activating factor (BAFF). Upon stimulation of the receptor, the canonical pathway is mediated through adapter proteins and kinases that eventually activate the IKB kinase (IKK) complex via activation of transforming growth factor $\beta$-activated kinase 1 (TAK1). Similarly, PI3K mediates signaling from GFR, TLRs, TCR, BCR, and cytokines feeds into activation of IKK via phosphorylation of AKT (protein kinase B) and IKK $\alpha$. Subsequently, polyubiquitination and site-specific phosphorylation of IKB protein via IKK complex leads to its proteasomal degradation. The released NF- $\mathrm{B}$ dimers translocate to the nucleus. Meanwhile, during the activation of the non-canonical pathway, TNF receptor-associated factor (TRAF) and cellular inhibitor of apoptosis (c-IAP) are recruited to the receptor as TRAF2/TRAF3/c-IAP1/2 complex. TRAF2/TRAF3 undergo proteasomal degradation allowing NF-KB-inducing kinase (NIK) levels to be stabilized. NIK then phosphorylates IKK $\alpha$ homodimer. Activated IKK $\alpha$ homodimer phosphorylates p100, leading to the partial degradation of p100 to p52. RelB/p52 heterodimers translocate to nucleus for further transcription. 
At homeostasis, NF-kB pathways are essential for regulating host defense responses against stress, injury and infection [13]. The pathways that are normally transient and self-limiting, have been shown to be excessively or constitutively active under disease condition. Dysregulation of NF- $\mathrm{KB}$ leads to the pathogeneses of cancer, inflammation, diabetes, and autoimmune disorders $[13,17,18,21]$. It is also implicated in the refraction of current therapies in both oncological [22,23] and non-oncological conditions [24]. These findings have generated very high interest in targeting the NF- $\mathrm{kB}$ pathway, but the real challenge exists in overcoming its ubiquitous physiological functions and have only contextual, tissue specific function [25-27].

NF- $\mathrm{KB}$ signaling cascades can be modulated at stages involving the receptor, IKK complex, gene transcription, post-translation or at any stage in between (Figure 2). This has been accomplished $[4,28]$ using small molecules, peptides, oligonucleotides, monoclonal antibodies (mAbs), and small interfering RNA (siRNA). Among these drugs, small molecules are of special interest due to the ease of designing, synthesizing and amending in drug development research $[29,30]$. Though riddled with challenges of selectivity, multiple targets and adverse drug reaction (ADR) in clinic, modern school of thoughts now encourage a molecule to hit multiple targets for a desired efficacy and to avoid resistance [31]. Moreover, even with the rising importance of biologic drugs in drug discovery, $76 \%$ of US-FDA (Food and Drug Administration-US) approved drugs in the last decade were still small molecules [32]. This encouraged us to review information regarding clinically relevant small molecule inhibitors of the NF- $\mathrm{KB}$ pathway from cell membrane receptor stimulation to nuclear signaling. Apart from evaluating the successes and failures of these small molecule NF- $\kappa B$ inhibitors during clinical trials, we also reviewed drugs that have been re-purposed after being shown to have NF- $\mathrm{kB}$ activity. We have consciously excluded herbal extract that often involves multiple components, but included small molecules isolated from natural products. Furthermore, we have focused only on modalities that inhibit the pathway as it has seen more clinical success than those activating cascade. Special emphasis has been given to molecules that were withdrawn or discontinued and the probable reason, if the same is disclosed in public domain. Molecules in clinical trials held-up at a stage with no further reports are often taken as drop-outs, but we have cannot consider them to be withdrawn due to absence of any credible information. 


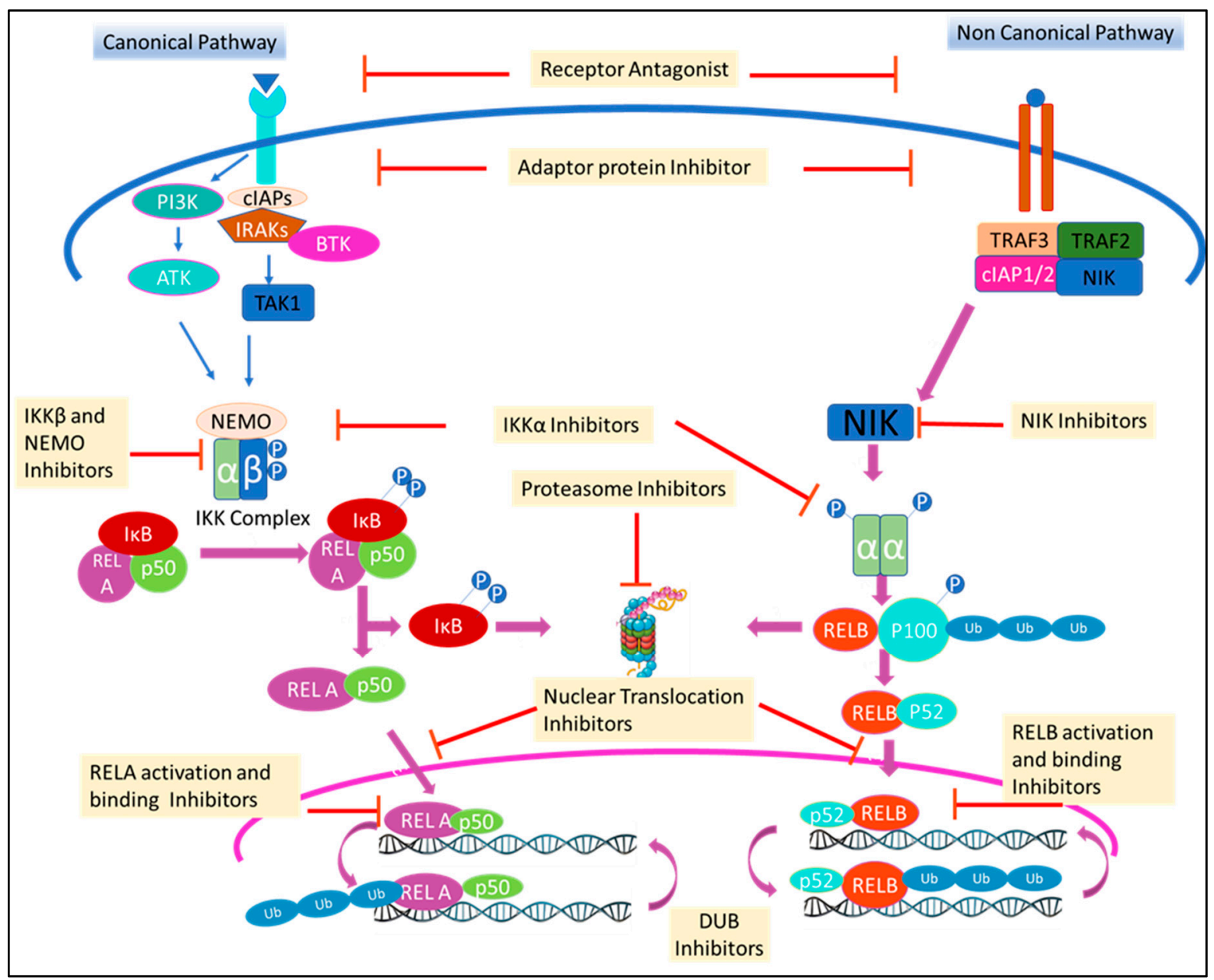

Figure 2. Canonical \& non-canonical NF- $\mathrm{BB}$ pathway and the site of interventions currently being explored for therapeutic benefit.

\section{Molecules that Inhibit Upstream IKK Complex in NF-kB Pathway}

\subsection{Inhibition of Cell Membrane Receptor Targets}

NF- $\mathrm{kB}$ signaling cascade are mostly initiated at the cell membrane through tumor necrosis factor- $\alpha$ receptor (TNFR), interleukin1 receptor (IL1R), toll-like receptor (TLR), T-cell receptors (TCR), B-cell receptors (BCR), growth factor receptors and TNF receptor superfamily (TNFRSF), such as lymphotoxin (LT) $\alpha / \beta$, cluster of differentiation (CD) 27, CD30, CD40, receptor activator of NF- $\mathrm{kB}$ (RANK), fibroblast growth factor-inducible 14 (Fn14), and B-cell activating factor (BAFF) receptors [33]. The cell surface receptors are most ideal targets to inhibit most of the pathways, but involved generally in protein-protein interaction (PPI), they lack binding sites for small molecules. They are mostly targeted by antibodies, siRNA, oligonucleotides, or peptides. With the advancement in biology, designing molecules to inhibit these receptors has become a lot easier and relatively smaller oligonucleotides or peptides have also been explored. Currently in the market, many drugs targeting the receptors are biologics such as mAbs and recombinant/fusion protein [34-36]. Viz, TNF blockers (Adalimumab, Certolizumab pegol, Etanercept and Infliximab), IL1R antagonist (Anakinra, Canakinumab), CD30 chimeric mAbs (Brentuximab vedotin), RANK ligand inhibitors (Denosumab). TNFR and IL1R mAbs are well-established and approved for various clinical indications, whereas in small molecule inhibitors, there is only one preclinical candidate. UCB-6786 by UCB pharma, a TNFR small molecule inhibitor, has only been tested for in vivo efficacy in collagen antibody induced arthritis mice model [37]. 
TLR signaling has been immensely studied for several years due to its indispensable role in various disease conditions such as cancer, inflammatory and autoimmune diseases. Both TLR agonist and TLR antagonist biologics have been testing extensively in clinical trials [38]. Focusing small molecule inhibitors, some TLR 4 and TLR7/8/9 antagonists have successfully entered various stages of clinical trials (Table 1). TLR7/8/9 antagonists are mostly antisense oligonucleotide (ASO) like Bazlitoran (IMO-8400), which was granted orphan drug status [39] for diffuse large B cell lymphoma (DLBCL) and Waldenstrom's Macroglobulinemia (WM). However, further studies were suspended for both indications [40]. Other ASO molecules such as IMO-3100 and IMO-9200, also did not go beyond phase 2 and phase 1 stage respectively. Only one small molecule TLR7/8/9 antagonist, CPG-52364 developed by Coley Pharmaceutical Group was taken into phase 1 trial for systemic lupus erythematosus (SLE) but was discontinued in 2010 (https://clinicaltrials.gov/ct2/show/NCT00547014). TLR4 antagonist, JKB-121, a small molecule inhibitor developed by TaiwanJ Pharmaceuticals for the non-alcoholic steatohepatitis (NASH) indication, is in jeopardy after it failed to demonstrate efficacy in a phase 2 placebo-controlled trial due to surprising positive response in the placebo arm [41]. In January 2019, JKB-122, another small molecule inhibitor of TLR 4, was reported to produce positive results from a phase 2 clinical trial evaluating its efficacy and safety during the treatment of patients with refractory autoimmune hepatitis. Moreover, the drug was demonstrated to be safe and well-tolerated in this study. As an orphan drug designation, the study results of JKB-122 provide a further opportunity for the autoimmune hepatitis (AIH) treatment [42] (Table 1).

Many TNFRSF inhibitors are successfully undergoing clinical trials for various indications including RANK ligand (RANKL) inhibitors. RANK signaling essential for the activation of osteoclasts, is mediated through the activation of the c-jun N-terminal kinase (JNK) and NF- $\mathrm{kB}$ pathways. Although RANK is activated by RANKL [43], it has been reported that even overexpression of RANK may itself activate the NF-KB pathway. Modulating the RANKL-RANK signaling axis has been a key strategy for diseases like osteoclastogenesis, bone destruction and even for many cancers [35]. Denosumab is a human recombinant monoclonal antibody against RANKL that has achieved orphan drug status [44] for bone cancer and malignant hypercalcemia and is currently marketed for these disease conditions along with other bone disorders, bone metastases, corticosteroid-induced osteoporosis, and male osteoporosis $[45,46]$. It is currently in phase 3 for breast cancer and non-small cell lung cancer (NSCLC) but there are concerns of increased risk of spontaneous multiple vertebral fractures upon denosumab discontinuation that has to be managed by bisphosphonate [47]. Most other molecules in clinical trials are also antibodies or nanobodies like JMT-103, IBI-307, and ALX-0141. Osteoprotegerin (OPG), a natural peptide that binds to the cytokine RANKL and prevents it from binding to RANK, has also been used to modulate this pathway. Amgen explored recombinant osteoprotegerin (AMGN-0007) but discontinued further studies on this molecule after incidents for bone disorders, cancer pain, postmenopausal osteoporosis, and RA. Similarly, Teva was developing an OPG analogue, CEP-37251, discovered by EvoGenix, and took it to phase 1 for osteoporosis but it was terminated. There is no small molecule inhibitor of RANKL in clinic, but with a better understanding of PPI disrupters, we expect to see one soon [48]. Similarly, other TNFRSF such as BAFF, LT $\beta$, CD27, CD30, CD40, OX40, and Fn14 also do not have any small molecule inhibitor in development. 
Table 1. Clinical small molecule inhibitors of cell membrane receptors in NF-kB pathway.

\begin{tabular}{|c|c|c|c|c|c|}
\hline Drug & Originator/Developer & Stage & Indication & Trail No. & Other Information \\
\hline \multicolumn{6}{|c|}{ Toll like Receptor 4 (TLR4) antagonist } \\
\hline \multirow{4}{*}{ Ibudilast (MN-166) } & \multirow{3}{*}{ MediciNova Inc } & Marketed in Japan & $\begin{array}{l}\text { Allergic conjunctivitis, Asthma, } \\
\text { Cerebrovascular disorders }\end{array}$ & $\begin{array}{l}\text { NCT01860807; } \\
\text { NCT04057898 }\end{array}$ & \multirow{4}{*}{$\begin{array}{l}\text { - Nonselective phosphodiesterase inhibitor } \\
\text { - } \quad \text { Neuroprotective benefit observed in clinic } \\
\text { - } \quad \text { and headache. }\end{array}$} \\
\hline & & Phase3 & Amyotrophic Lateral Sclerosis & NCT04057898 & \\
\hline & & Phase $1 / 2$ & Glioblastoma & NCT03782415 & \\
\hline & MediciNova Inc/NIH & Phase 2 & MS & NCT01982942 & \\
\hline \multirow[t]{4}{*}{ JKB-122 } & \multirow{4}{*}{$\begin{array}{c}\text { Jenken } \\
\text { Biosciences/TaiwanJ } \\
\text { Pharmaceuticals }\end{array}$} & Phase 3 & Autoimmune Hepatitis & NCT04371718 & \multirow{4}{*}{$\begin{array}{l}\text { Out licensed to Newsoara Biopharma for } \\
\text { clinical development of JKB-122 and for } \\
\text { preclinical research of JKB-133. } \\
\text { Successfully achieved primary endpoint in } \\
\text { phase } 2 \text { Autoimmune Hepatitis study. } \\
\text { - } \quad \text { Study in HCV patients terminated after } \\
\text { completing phase } 1 .\end{array}$} \\
\hline & & Phase 2 & Autoimmune Hepatitis & NCT02556372 & \\
\hline & & Phase 2 & Chronic hepatitis C & NCT02293941 & \\
\hline & & Phase 2 & NASH & NCT04255069 & \\
\hline \multirow{2}{*}{$\begin{array}{l}\text { VB-201 (TLR2/4 } \\
\text { antagonist) }\end{array}$} & \multirow[t]{2}{*}{ VBL Therapeutics } & Phase 2 & Psoriasis & $\begin{array}{l}\text { NCT01001468; } \\
\text { NCT01837420 }\end{array}$ & \multirow{2}{*}{$\begin{array}{l}\text { - Did not meet primary endpoint in Psoriasis } \\
\text { and Ulcerative Colitis [49]. } \\
\text { - Currently in preclinical trials for } \\
\text { Non-alcoholic fatty liver disease. }\end{array}$} \\
\hline & & Phase 2 & Ulcerative colitis & NCT01839214 & \\
\hline JKB-121 & $\begin{array}{l}\text { Manal Abdelmalek, Duke } \\
\text { University/TaiwanJ } \\
\text { Pharmaceuticals }\end{array}$ & Phase 2 & $\mathrm{NASH}$ & NCT02442687 & $\begin{array}{l}\text { - Failed to demonstrate efficacy due to } \\
\text { surprising positive response in the placebo } \\
\text { arm and discontinued for NASH. }\end{array}$ \\
\hline \multicolumn{6}{|c|}{ Toll like Receptor 7 (TLR7) antagonist } \\
\hline CPG-52364 & Pfizer & Phase 1 & Healthy Volunteers (For SLE) & NCT00547014 & Discontinued for SLE in Jan 2020. \\
\hline
\end{tabular}

Abbreviations: ALT—alanine aminotransferase; MS—multiple sclerosis; NASH—Non-alcoholic steatohepatitis; NIH—National Institutes of Health; SLE—systemic lupus erythematosus. 


\subsection{Inhibition of Receptor Adaptor Protein}

\subsubsection{Bruton's Tyrosine Kinase (BTK) Inhibitors}

BTK and other Tec family of non-receptor tyrosine kinases act as a platform for bringing together a diverse array of signaling proteins. Among the Tec family kinases, BTK is one of the successfully explored targets with almost 50 molecules entering clinical trials and a couple of others launched for multiple indication $[50,51]$.

Small molecule inhibitor, Ibrutinib was developed for chronic lymphocytic leukemia (CLL), mantle cell lymphoma (MCL), graft-versus-host disease (GVHD), marginal zone lymphoma (MZL), and WM. However, this molecule was terminated for further evaluation during the studies of many other cancers at different stages, including breast cancer, rheumatoid arthritis (RA), and seasonal allergic rhinitis (SAR). Acalabrutinib is currently marketed for MCL and in collaboration with AstraZenca was recently approved [52] (Nov.2019) for CLL or small lymphocytic lymphoma (SLL). Zanubrutinib was recently granted [53] an accelerated approval by the US-FDA for MCL as a second line of therapy and preregistered for CLL (Table 2).

Many other superior BTK inhibitors are still in different stages of clinical trials (Table 2). Compared to Ibrutinib, Orelabrutinib has a better response rate and superior safety profile in a phase 2 study with relapsed or refractory MCL patients [54]. Tirabrutinib was granted the orphan drug status and is now preregistered for lymphoma [55]. Recently (Dec.2019) safety and efficacy data from a phase 2 study against CLL [56] and long term safety study with this compound in MCL [57] were disclosed. An oral, reversible covalent BTK inhibitor, Rilzabrutinib is currently in phase 3 for pemphigus. Meanwhile, orally active, brain-penetrant SAR-442168 recently [58] met primary end point for phase 2 trials of relapsing multiple sclerosis (MS) and is entering phase 3 trial later this year in relapsing and progressive MS. ABBV-105 is going through phase 2 for RA and SLE, but for better clinical success, it is being explored in combination (renamed as ABBV-559) with JAK1 inhibitor (Upadacitinib) for the same disease (Table 2).

Dasatinib, a small molecule inhibitor of Bcr-abl tyrosine kinase and Src-Family kinase and later found to be a BTK inhibitor as well, was launched for CLL. It is in different stages for other cancers, but is discontinued for pancreatic cancer [59] and scleroderma due to adverse events and reports of spontaneous pulmonary arterial hypertension [60]. Similarly, EGFR inhibitors (Olafertinib and DZD-9008) were later found to inhibit BTK. BMS-986142 and Fenebrutinib by BMS and Genentech were taken to clinic for many indications, but the studies were terminated or completed without any significant outcome due to various reasons, respectively. Many other small molecule BTK inhibitors like CT-1530, BIIB-068, TAK-020 or GDC-0834 were also discontinued or no development was reported in phase 1 itself (Table 2). 
Table 2. Clinical small molecule inhibitors of cellular receptors adaptor protein in NF-kB pathway.

\begin{tabular}{|c|c|c|c|c|c|}
\hline Drug & Originator/Developer & Stage & Indication & Trail No. & Other Information \\
\hline \multicolumn{6}{|c|}{ Bruton's tyrosine kinase (BTK) inhibitors } \\
\hline \multirow{4}{*}{ Zanubrutinib } & \multirow{4}{*}{ BeiGene } & Launched at 2019 & MCL & NCT04002297 & \multirow{4}{*}{$\begin{array}{l}\text { - BRUKINSA oral dose is } 160 \mathrm{mg} \text { twice daily or } \\
320 \mathrm{mg} \text { once daily. } \\
\text { - TEAE: Decreased neutrophil count, platelet } \\
\text { count and hemoglobin [53]. } \\
\text { - Case reports of Hepatitis-B reactivation. }\end{array}$} \\
\hline & & Preregistration & CLL & NCT03734016 & \\
\hline & & Phase 3 & BCL, RRWM & NCT03332173 & \\
\hline & & Phase 2 & $\begin{array}{l}\text { DLBCL, Follicular lymphoma, } \\
\text { Lymphoma, CLL, } \\
\text { Lymphosarcoma, FL, MZL }\end{array}$ & $\begin{array}{l}\text { NCT03145064; } \\
\text { NCT04282018 }\end{array}$ & \\
\hline \multirow{12}{*}{ Acalabrutinib } & AstraZeneca/Parexel & Phase 3 & CLL & NCT04008706 & \multirow{12}{*}{$\begin{array}{l}\text { Potentially serious TEAE: Severe bone marrow } \\
\text { suppression, infections, bleeding, tumor lysis } \\
\text { syndrome, and renal toxicity [61]. } \\
\text { - } \quad \text { Report of Atrial-flutter in an off-label use. } \\
\text { - Herpes zoster infection and a case of } \\
\text { Hepatitis-B reactivation observed. }\end{array}$} \\
\hline & $\begin{array}{l}\text { Acerta Pharma/AstraZeneca, } \\
\text { Biologics Inc, Merck }\end{array}$ & Launched 2017 & MCL & NCT02972840 & \\
\hline & Acerta Pharma & Phase 3 & CLL & NCT02970318 & \\
\hline & \multirow[t]{2}{*}{ Acerta Pharma/AstraZeneca } & Phase 2 & COVID-19 & $\begin{array}{l}\text { NCT04346199, } \\
\text { NCT04380688 }\end{array}$ & \\
\hline & & Phase 2 & Chronic GVHD & NCT04198922 & \\
\hline & \multirow{3}{*}{ Acerta Pharma } & Phase 2 & WM & NCT02180724 & \\
\hline & & Phase 2 & Metastatic Pancreatic Cancer & NCT02570711 & \\
\hline & & Phase 2 & RA & NCT02387762 & \\
\hline & \multirow{3}{*}{$\begin{array}{c}\text { Acerta Pharma BV } \\
\text { Merck Sharp \& Dohme Corp. }\end{array}$} & Phase 2 & Ovarian Cancer & NCT02537444 & \\
\hline & & Phase 2 & NSCLC & NCT02448303 & \\
\hline & & Phase 2 & $\begin{array}{l}\text { Squamous Cell Carcinoma of } \\
\text { the Head and Neck }\end{array}$ & NCT02454179 & \\
\hline & $\begin{array}{l}\text { Acerta Pharma/Swedish } \\
\text { Medical centre }\end{array}$ & Phase 2 & DLBCL & NCT03736616 & \\
\hline \multirow{7}{*}{ Ibrutinib } & \multirow{4}{*}{$\begin{array}{l}\text { Janssen/Pharmacyclics; M.D. } \\
\text { Anderson Cancer Center }\end{array}$} & Launched 2013 & CLL & NCT02801578 & \multirow{7}{*}{$\begin{array}{l}\text { - } 420 \text { mg orally once daily dose for CLL. } \\
\text { - Serious TEAE: hemorrhage, hypertension, } \\
\text { ventricular arrhythmias, atrial fibrillation, } \\
\text { atrial flutter, decrease in blood cell counts and } \\
\text { Tumor lysis syndrome. } \\
\text { - Invasive fungal infections and Hepatitis-B } \\
\text { reactivation observed. } \\
\text { Ibrutinib-induced autoimmune hemolytic } \\
\text { anemia and rare nail plate abnormalities also } \\
\text { seen [62]. }\end{array}$} \\
\hline & & Launched 2013 & WM & NCT02165397 & \\
\hline & & Launched 2013 & MCL & NCT01646021 & \\
\hline & & Phase 2 & GVHD & NCT02195869 & \\
\hline & \multirow{3}{*}{ Janssen/Pharmacyclics } & Phase 3 & $\begin{array}{l}\text { Metastatic Pancreatic } \\
\text { Adenocarcinoma }\end{array}$ & NCT02436668 & \\
\hline & & Phase 3 & DLBCL & NCT01855750 & \\
\hline & & Phase 3 & RRCLL, SLL & NCT01578707 & \\
\hline
\end{tabular}


Table 2. Cont

\begin{tabular}{|c|c|c|c|c|c|}
\hline Drug & Originator/Developer & Stage & Indication & Trail No. & Other Information \\
\hline \multirow{9}{*}{ Dasatinib } & $\begin{array}{l}\text { BMS/Dana-Farber Cancer } \\
\text { Institute }\end{array}$ & Launched 2006 & $\begin{array}{l}\text { CML, acute cell lymphoblastic } \\
\text { leukemia-lymphoma }\end{array}$ & $\begin{array}{l}\text { NCT00123487, } \\
\text { NCT03020030 }\end{array}$ & \multirow{9}{*}{$\begin{array}{l}\text { - TEAE: Cytopenias, fluid retention, pleural } \\
\text { effusion, dyspnea, gastrointestinal disorders, } \\
\text { skin rash, headache and fatigue [63]. } \\
\text { - Low blood cell count, Pulmonary Arterial } \\
\text { Hypertension and Tumor lysis syndrome } \\
\text { also seen. } \\
\text { - Often requires dose interruption and/or } \\
\text { dose reduction. }\end{array}$} \\
\hline & BMS & Phase 3 & Prostatic Neoplasms & NCT00744497 & \\
\hline & BMS/NCI & Phase 2 & DLBCL & NCT00608361 & \\
\hline & DINIS/INCI & Phase 2 & Rhabdomyosarcoma & NCT0304170 & \\
\hline & $\begin{array}{l}\text { BMS/OSI pharma/M.D. } \\
\text { Anderson Cancer Center }\end{array}$ & Phase 2 & NSCLC & NCT00826449 & \\
\hline & \multirow{2}{*}{$\begin{array}{l}\text { BMS/Massachusetts General } \\
\text { Hospital }\end{array}$} & Phase 2 & CLL & NCT00438854 & \\
\hline & & Phase 2 & Cholangiocarcinoma & NCT02428855 & \\
\hline & BMS & Phase 2 & Breast Cancer & NCT00767520 & \\
\hline & BMS/Jorge J. Castillo, MD & Phase 2 & WM & NCT04115059 & \\
\hline \multirow{2}{*}{ Tirabrutinib } & $\begin{array}{l}\text { Ono Pharmaceutical/Gilead } \\
\text { Sciences }\end{array}$ & Registered & Lymphoma & NCT03162536 & \multirow{2}{*}{$\begin{array}{l}\text { - TEAE: neutropenia, lymphopenia, leukopenia, } \\
\text { and erythema multiforme [64]. } \\
\text { - Also observed pneumocystis jirovecii } \\
\text { pneumonia and interstitial lung disease in a } \\
\text { patient at highest dose of } 480 \mathrm{mg} \text { QD. }\end{array}$} \\
\hline & $\begin{array}{l}\text { Ono Pharmaceutical/Gilead } \\
\text { Sciences }\end{array}$ & Preregistration & WM & NCT03740529 & \\
\hline Rilzabrutinib & Principia Biopharma & Phase 3 & Pemphigus vulgaris & NCT02704429 & $\begin{array}{l}\text { Orphan drug status for Pemphigus vulgaris and } \\
\text { Idiopathic thrombocytopenic purpura. }\end{array}$ \\
\hline \multirow[t]{2}{*}{ Evobrutinib } & Merck Serono/EMD Serono & Phase 3 & MS & NCT04032158 & \multirow{2}{*}{$\begin{array}{l}\text { TEAE: Nasopharyngitis and increases in levels of } \\
\text { alanine aminotransferase, aspartate } \\
\text { aminotransferase and lipase [65]. }\end{array}$} \\
\hline & Merck Serono/EMD Serono & Phase 2 & RA & NCT02784106 & \\
\hline \multirow[t]{2}{*}{ Orelabrutinib } & \multirow[t]{2}{*}{ InnoCare Pharma/Beijing } & \multirow[t]{2}{*}{ Phase 2} & SLE & & \multirow{2}{*}{$\begin{array}{l}\text { - TEAE: thrombocytopenia and } \\
\text { neutropenia [66]. } \\
\text { - } \quad \text { Profile better than Ibrutinib. }\end{array}$} \\
\hline & & & MZL & & \\
\hline \multirow{2}{*}{ ABBV-105 } & \multirow{2}{*}{ AbbVie } & \multirow{2}{*}{ Phase 2} & SLE & NCT03978520 & \multirow{3}{*}{$\begin{array}{l}\text { Focus is on ABBV-599 which is the } \\
\text { ABBV-105/upadacitinib-combination }\end{array}$} \\
\hline & & & RA & NCT03682705 & \\
\hline ABBV-599 & AbbVie & Phase 2 & RA, SLE & $\begin{array}{l}\text { NCT03682705, } \\
\text { NCT03978520 }\end{array}$ & \\
\hline
\end{tabular}


Table 2. Cont.

\begin{tabular}{|c|c|c|c|c|c|}
\hline Drug & Originator/Developer & Stage & Indication & Trail No. & Other Information \\
\hline SAR-442168 & Principia Biopharma/Sanofi & Phase 2 & Relapsing MS & NCT03996291 & $\begin{array}{l}\text { Common TEAE: Headache, upper respiratory tract } \\
\text { infection and nasopharyngitis [67]. }\end{array}$ \\
\hline Branebrutinib & BMS & Phase 2 & RA, SLE, Sjogren's syndrome & NCT04186871 & In phase 1, no serious TEAE observed [68]. \\
\hline TAS-5315 & Taiho Pharmaceutical & Phase 2 & RA & NCT03605251 & $\begin{array}{l}\text { Observed decrease in platelet aggregation and } \\
\text { prolonged bleeding time in phase } 1 \text { [69]. }\end{array}$ \\
\hline Remibrutinib & Novartis & Phase 2 & $\begin{array}{l}\text { Asthma, Sjogren's syndrome, } \\
\text { Urticaria }\end{array}$ & $\begin{array}{l}\text { NCT03944707, } \\
\text { NCT04035668, } \\
\text { NCT04109313 }\end{array}$ & $\begin{array}{l}\text { Phase } 2 \text { trial in Urticaria suspended due to } \\
\text { COVID-19. }\end{array}$ \\
\hline \multirow{2}{*}{ BMS-986142 } & \multirow{2}{*}{ BMS } & \multirow{2}{*}{ Phase 2} & RA & NCT02638948 & \multirow{2}{*}{$\begin{array}{l}\text { - } \quad \text { TEAE: dizziness and nausea. } \\
\text { - Increase in Alanine aminotransferase [70]. }\end{array}$} \\
\hline & & & Sjogren's syndrome & NCT02843659 & \\
\hline Fenebrutinib & Genentech & Phase 2 & Urticaria & NCT03693625 & Higher doses may increase liver enzymes [71]. \\
\hline Poseltinib & $\begin{array}{l}\text { Hanmi Pharmaceutical/Eli } \\
\text { Lilly }\end{array}$ & Phase 2 & RA & NCT02628028 & $\begin{array}{l}\text { Phase } 2 \text { discontinued as study failed to demonstrate } \\
\text { its target effectiveness in the interim results [72]. }\end{array}$ \\
\hline \multirow{2}{*}{ Spebrutinib } & \multirow{2}{*}{ Celegene } & Phase 2 & RA & NCT01975610 & \multirow{2}{*}{ Celgene acquired by Bristol-Myers Squibb. } \\
\hline & & Phase 1 & CLL & NCT01732861 & \\
\hline \multirow{3}{*}{ DTRMWXHS-12 } & \multirow{3}{*}{ Zhejiang DTRM Biopharma } & Phase 2 & $\begin{array}{l}\text { DLBCL, R and RCLL, } \\
\text { Follicular Lymphoma }\end{array}$ & NCT04305444 & \multirow{2}{*}{ No development reported for B-cell lymphoma. } \\
\hline & & Phase 1 & MCL & NCT03836768 & \\
\hline & & Phase 1 & CLL, BCL & NCT02891590 & Evaluate the safety, tolerability and PK profile. \\
\hline CT-1530 & $\begin{array}{l}\text { Centaurus Biopharma Co., } \\
\text { Ltd. }\end{array}$ & Phase $1 / 2$ & B Cell-NHL, CLL, WM & NCT02981745 & Discontinued for all indications \\
\hline REDX08608 & Redx Pharma/Loxo oncology & Phase $1 / 2$ & CLL/SLL or NHL & NCT03740529 & In basal cell cancer, no development reported. \\
\hline M-7583 & EMD Serono & Phase $1 / 2$ & $\begin{array}{c}\text { MCL, DLBCL, } \\
\text { Relapsed/Refractory B Cell } \\
\text { Malignancies }\end{array}$ & NCT02825836 & $\begin{array}{l}\text { TEAE: Neutropenia, febrile neutropenia and } \\
\text { pneumonia [73]. }\end{array}$ \\
\hline ARQ-531 & ArQule/Merck & Phase $1 / 2$ & Hematological malignancies & NCT03162536 & Well-tolerated through $65 \mathrm{mg}$ QD [74]. \\
\hline Vecabrutinib & $\begin{array}{l}\text { Biogen Idec, Sunesis } \\
\text { Pharmaceuticals }\end{array}$ & Phase $1 / 2$ & Hematological malignancies & NCT03037645 & TEAE: Anemia, headache and night sweats. \\
\hline TAK-020 & Takeda & Phase 1 & RA & NCT02413255 & $\begin{array}{l}\text { TEAE; Abdominal distension, upper abdominal } \\
\text { pain, nausea, and headache }\end{array}$ \\
\hline BIIB068 & Biogen & Phase 1 & SLE & NCT02829541 & No update beyond phase 1 \\
\hline
\end{tabular}


Table 2. Cont.

\begin{tabular}{|c|c|c|c|c|c|}
\hline Drug & Originator/Developer & Stage & Indication & Trail No. & Other Information \\
\hline AC-0058TA & ACEA Biosciences & Phase 1 & SLE & NCT03878303 & $\begin{array}{l}\text { Phase } 1 \text { for Autoimmune disorders completed in } \\
2017 \text { and no further progress reported. }\end{array}$ \\
\hline SN-1011 & Sinomab & Phase 1 & Autoimmune disorder & NCT04041544 & \\
\hline BIIB-091 & Biogen & Phase 1 & Healthy Volunteer (MS) & NCT03943056 & Completes phase 1 trial for Multiple sclerosis. \\
\hline TG-1701 & $\begin{array}{l}\text { Eternity Bioscience/TG } \\
\text { Therapeutics }\end{array}$ & Phase 1 & $\begin{array}{l}\text { Healthy Volunteer (NHL, } \\
\text { CLL) }\end{array}$ & NCT04291846 & Encouraging safety profile. \\
\hline CG-806 & $\begin{array}{l}\text { CrystalGenomics, Aptose } \\
\text { Biosciences }\end{array}$ & Phase 1 & CLL, SLL, NHL & NCT03893682 & No drug-related dose-limiting toxicities. \\
\hline \multicolumn{6}{|c|}{ Interleukin-1 receptor-associated kinase (IRAK) inhibitors } \\
\hline PF-06650833 & Pfizer & Phase 2 & RA & NCT02996500 & TEAE: Infections and infestations [75]. \\
\hline \multirow{2}{*}{ CA-4948 } & \multirow{2}{*}{ Curis Pharmaceuticals } & \multirow{2}{*}{ Phase 1} & AML, MDS & NCT04278768 & \multirow{2}{*}{$\begin{array}{l}\text { Adverse events: amylase/lipase increased neutrophi } \\
\text { count decreased, rash and rhabdomyolysis [76]. }\end{array}$} \\
\hline & & & Hematological malignancies & NCT03328078 & \\
\hline R-835 & Rigel Pharmaceuticals & Phase 1 & $\begin{array}{c}\text { Autoimmune and } \\
\text { Inflammatory Diseases }\end{array}$ & & Rigel initiates phase 1 clinical trial [77]. \\
\hline \multirow{3}{*}{ BAY-1834845 } & \multirow{3}{*}{ Bayer } & \multirow{3}{*}{ Phase 1} & Pelvic Inflammatory Disease & NCT03054402 & \multirow{3}{*}{$\begin{array}{c}\text { No update beyond phase } 1 \text { for Pelvic Inflammatory } \\
\text { Disease }\end{array}$} \\
\hline & & & Inflammation & NCT03244462 & \\
\hline & & & Psoriasis & NCT03493269 & \\
\hline \multirow{2}{*}{ BAY-1830839 } & \multirow{2}{*}{ Bayer } & \multirow{2}{*}{ Phase 1} & RA & NCT03540615 & \\
\hline & & & Health volunteers (For RA) & NCT03965728 & \\
\hline \multicolumn{6}{|c|}{ Cellular Inhibitor of Apoptosis Proteins (c-IAP) inhibitors } \\
\hline \multirow[t]{2}{*}{$\begin{array}{l}\text { Birinapant } \\
\text { (TL32711) }\end{array}$} & $\begin{array}{l}\text { Jonsson Comprehensive } \\
\text { Cancer Center, NCI }\end{array}$ & Phase 2 & $\begin{array}{l}\text { High Grade Ovarian, } \\
\text { Fallopian Tube, Primary } \\
\text { Peritoneal Cancer }\end{array}$ & NCT02756130 & \multirow{2}{*}{$\begin{array}{l}\text { Birinapant and pembrolizumab combination had } \\
\text { futile outcome in patients with MSS colorectal } \\
\text { cancer [78]. }\end{array}$} \\
\hline & TetraLogic Pharmaceuticals & Phase 1 & Hepatitis B & NCT02288208 & \\
\hline
\end{tabular}


Table 2. Cont.

\begin{tabular}{|c|c|c|c|c|c|}
\hline Drug & Originator/Developer & Stage & Indication & Trail No. & Other Information \\
\hline \multirow{4}{*}{$\begin{array}{l}\text { APG-1387 } \\
\text { (SM-1387) }\end{array}$} & \multirow{3}{*}{ Ascentage Pharma } & Phase 2 & Advanced Solid Tumors & NCT04284488 & \multirow{4}{*}{$\begin{array}{l}\text { - TEAE: Elevated bilirubin, lipase increase and } \\
\text { shortness of breath [79]. } \\
\text { - Exploring for Hepatitis B in both } \\
\text { Treatment-experienced and naïve patient. }\end{array}$} \\
\hline & & Phase 2 & Myelofibrosis & NCT04354727 & \\
\hline & & Phase 1 & $\begin{array}{l}\text { Advanced Solid Tumors or } \\
\text { Hematologic Malignancies }\end{array}$ & NCT03386526 & \\
\hline & $\begin{array}{l}\text { Ascentage Pharma, } \\
\text { HealthQuest Pharma }\end{array}$ & Phase 1 & Chronic Hepatitis B & NCT03585322 & \\
\hline \multirow{9}{*}{ LCL-161 } & Mayo Clinic & Phase 2 & RR Plasma Cell Myeloma & NCT01955434 & \multirow{9}{*}{$\begin{array}{l}\text { - Hematologic toxicities: thrombocytopenia and } \\
\text { anemia [80]. } \\
\text { - Completed phase I trial in multiple myeloma. } \\
\text { - No development reported for pancreatic cancer } \\
\text { and solid tumors. }\end{array}$} \\
\hline & $\begin{array}{l}\text { MD Anderson Cancer Center, } \\
\text { NCI, Novartis }\end{array}$ & Phase 2 & Myelofibrosis & NCT02098161 & \\
\hline & \multirow[b]{2}{*}{ Novartis Pharmaceuticals } & Phase 2 & Breast Cancer & NCT01617668 & \\
\hline & & Phase 2 & $\begin{array}{l}\text { Small Cell Lung Cancer } \\
\text { Ovarian Cancer }\end{array}$ & NCT02649673 & \\
\hline & $\begin{array}{l}\text { US Oncology Research } \\
\text { Novartis, Delta Clinical } \\
\text { Research, LLC }\end{array}$ & Phase 1 & Metastatic Pancreatic Cancer & NCT01934634 & \\
\hline & \multirow{4}{*}{ Novartis Pharmaceuticals } & Phase 1 & Neoplasms & NCT01968915 & \\
\hline & & Phase 1 & Solid Tumors & NCT01240655 & \\
\hline & & Phase 1 & Advanced Solid Tumors & NCT01098838 & \\
\hline & & Phase 1 & MM & NCT03111992 & \\
\hline ASTX660 & Astex Pharmaceuticals & Phase 1 & AML & NCT04155580 & $\begin{array}{l}\text { Common TEAE: Anemia, increased lipase and } \\
\text { lymphopenia [81]. }\end{array}$ \\
\hline $\begin{array}{l}\text { Debio } 1143 \\
\text { (AT-406) }\end{array}$ & Debiopharm & Phase 1 & $\begin{array}{l}\text { Advanced Solid Tumors and } \\
\text { Lymphomas }\end{array}$ & NCT01078649 & TEAE: Mucositis, dysphagia and anemia [82]. \\
\hline CUDC-427 & Curis Pharmaceuticals & Phase 1 & Lymphoma & NCT01908413 & $\begin{array}{l}\text { Few patients discontinued and TEAE includes } \\
\text { pruritus and fatigue [83]. }\end{array}$ \\
\hline
\end{tabular}

Abbreviations: AML—acute myeloid leukemia; BCL-B-cell leukemia; BMS—Bristol-Myers Squibb; CLL—chronic lymphocytic leukemia; CML—chronic myeloid leukemia; CMML—chronic myelomonocytic leukemia; DLBCL—diffuse large B-cell lymphoma; GVHD—graft versus host disease; HCC-hepatocellular Carcinoma; MCL-Mantle cell lymphoma; MDS-Myelodysplastic Syndrome; MM-Multiple myeloma; MS-multiple sclerosis; MZL-marginal zone lymphoma; NHL-Non-Hodgkin lymphoma; NSCLC-non-small cell lung cancer; RA—rheumatoid arthritis; RRCLL—relapsed and refractory chronic lymphocytic leukemia; RRMM—relapsed and refractory Multiple myeloma; SLL—small lymphocytic lymphoma; SLE-systemic lupus erythematosus; TCL-T-Cell Lymphoma; TEAE-Treatment-emergent adverse effects; WM-Waldenstrom macroglobulinemia. 


\subsubsection{Interleukin-1 Receptor-associated Kinase (IRAK)}

IRAK is the downstream target of TLR and IL1R and the activation of these receptors initiate signaling cascade through MYD88 adaptor protein. This signaling subsequently involving IRAK and IKK complex, leads to NF- $\mathrm{KB}$ mediated transcription of certain genes that are involved in various inflammation condition. Quite often, components of this pathway are found to be genetically altered, resulting in specific human cancers [84]. The central role of IRAK in these signaling pathways makes them an attractive target for treating diseases with MYD88 gene mutations as observed in B-cell malignancies [84] and certain inflammatory diseases [85] (Table 2).

The most advanced IRAK small molecule inhibitor, Pacritinib, which primarily targets Janus Kinase 2 (JAK2) and Fms-like tyrosine kinase 3 (FLT3), also inhibits IRAK1 [86]. In 2019, dual IRAK1/4 inhibitor, R-835, successfully completed phase 1 study for autoimmune disorder. Among selective IRAK4 reversible inhibitors, PF-06650833, which is currently at phase 2 for RA and hidradenitis suppurativa, is the front runner and has favorable safety and pharmacokinetic profile from a phase 1 study [75]. Orally active CA-4948 (AU-4948) that was out-licensed to Curis by Aurigene, is currently in phase 1 for acute myeloid leukemia (AML), Myelodysplastic syndromes and non-Hodgkin lymphoma (NHL) [87]. Though, it also inhibits FLT3, it is being showcased as an IRAK4 inhibitor. BAY-1834845 was considered for pelvic inflammatory disorders, psoriasis and RA, but there is no update since the phase 1 trial, which was completed in 2018. BAY-1830839 for RA completed its phase 1 study with increasing single oral doses mid of last year. There were investigations also conducted for safety, tolerability, and pharmacokinetics during increasing repeated oral doses and potential drug-drug interactions with midazolam and methotrexate (Table 2).

\subsubsection{Phosphatidyl Inositol-3 Kinases (PI3K)/AKT}

PI3K, a lipid kinase, mediates signaling from growth factors, cytokines, TLRs, TCR, BCR, and cell stress. The PI3K mediated signaling activates one of its signaling cascades involving the NF- $\mathrm{KB}$ pathway through direct activation of IKK via phosphorylation of IKK $\alpha$ [88] and also through AKT (also known as protein kinase B) phosphorylation eventually leading to NF- $\mathrm{KB}$ signaling [89,90]. PI3K comprises of one catalytic p110 subunit and two regulatory p 85 and p55 subunits. Based on different structures and specific substrates of PI3K, it is divided into three classes called Class I, II, and III PI3Ks and of these Class I are majorly explored. Class I PI3Ks classified as class IA and class IB further Class1A consists three isoforms PI3K $\alpha, \mathrm{PI} 3 \mathrm{~K} \beta$, and PI3K $\delta$ and their catalytic subunits are $\mathrm{p} 110 \alpha, \mathrm{p} 110 \beta$, and p1108, respectively, while p110 $\gamma$ catalytic subunit represents class IB. PI3K P110 $\alpha$ is strongly correlated with angiogenesis, while $\mathrm{p} 110 \beta, \delta$, and $\gamma$ contribute to inflammatory responses [91-93].

At basal conditions, the p110 catalytic subunit gets stabilization by forming a heterodimer with regulatory p85 subunit $[94,95]$. Upon stimulation, phosphorylation p85 regulatory subunit of PI3K leads to the activation of the p110 catalytic subunit. The activated PI3K heterodimer (viz. p110 $\alpha$ and p85) induce the conversion of phosphatidylinositol 4,5 bisphosphate (PIP2) to phosphatidylinositol $(3,4,5)$-trisphosphate (PIP3). PIP3, a second messenger binds to downstream targets and leads into its signaling cascades involving NF- $\mathrm{kB}$ pathways through direct activation of IKK via phosphorylation of IKK or through AKT phosphorylation and subsequent activation of p65 through IKK complex $[89,90,95,96]$.

Inhibition of PI3K or any downstream target like AKT will effectively modulate the signaling cascade including activation and NF- $\mathrm{KB}$-dependent gene expression. Many PI3K and AKT inhibitors have been taken into clinical trials for a multitude of diseases and are extensively reviewed in the literature $[95,97,98]$. Some of the PI3K inhibitors are even approved for different indications. Many of them are designed to be active against the specific isoform like Idelalisib and Alpelisib, predominantly active against PI3K $\alpha$ isoform and thus may have reduced ADR. On the other hand, for better efficacy profile, Copanlisib blocks both PI3K $\alpha$ and PI3K $\delta$ isoforms and Duvelisib specifically inhibits the Class1A PI3K $\delta$ and Class1B PI3K. To date, no AKT inhibitor has been approved in the market but many are in clinical trials $[92,95]$. 


\subsubsection{Cellular Inhibitor of Apoptosis Proteins (c-IAP)}

IAPs comprise of a family of eight member proteins that are well known for their ability to prevent apoptosis through inhibiting caspase activation or activity. Their role as anti-apoptotic proteins and their dysregulation, either by overexpression or loss of endogenous antagonists, is associated with tumor growth, poor prognosis, and resistance to treatment, making them attractive targets [99]. Recent discoveries have shown that cIAP1, cIAP2, and X-linked IAP (XIAP) also regulate signaling pathways of the innate immune system by ubiquitylating their substrates. Moreover, cIAP1 and cIAP2 inhibit the TNF receptor mediated apoptosis through blocking the caspase- 8 activation by TRAF2 interaction [100].

In TNF- $\alpha$ induced inflammatory pathway, cIAP1/2 plays a vital role in NF- $\mathrm{kB}$ activation. Binding of TNF- $\alpha$ to TNFR recruits TNFR-associated death domain protein (TRADD), receptor-interacting protein kinase 1 (RIPK1), TRAF2, and cIAP1/2 to form complex for NF-kB signaling [101]. IAPs have a carboxy-terminal RING (really interesting new gene) domain which allows them to act as ubiquitin E3 ligases that facilitate to conjugate themselves and with associated proteins such as RIPK1 through K11, K48, and K63-linked ubiquitin chains. This ubiquitin chain facilitates the docking of TAB2/3/TAK1 and the IKK subunit NF- $\mathrm{KB}$ essential modulator (NEMO), eventually leading to NF-KB dependent and mitogen-activated protein kinase (MAPK) dependent inflammation, proliferation, and cell survival [102]. Apart from inhibiting caspase activation, ubiquitin E3 ligases property of cIAP1/2 encouraged the researcher to explore cIAP1/2 in an immune and inflammatory target $[100,101,103,104]$.

ASTX660, a non-peptidomimetic small molecule antagonist of CIAP1/2 and XIAP (X-linked inhibitor of apoptosis protein), is in phase $1 / 2$ study for advanced solid tumors and lymphomas and phase 2 study for Peripheral and Cutaneous T-Cell Lymphoma (TCL) [105] (Table 2). Second mitochondria-derived activator of caspase (SMAC) mimetic, AT406 (Debio-1143), the small molecule IAP antagonist, based on clinically compelling phase 2 results (by Debiopharm) recently (February 2020) got breakthrough therapy status in head and neck cancer [82]. AT406 also achieved orphan drug status for Ovarian cancer [106] and is in phase 2 for solid tumor. Another SMAC mimetic, APG-1387, inhibits cIAP1/2 and XIAP and got approved in February 2020 for phase 1b/2 trial in China for solid tumors [107]. LCL-161 didn't progress beyond phase 2 trials for breast cancer, multiple myeloma (MM) and myelofibrosis but a recently concluded phase 1 combination study for MM (https:/clinicaltrials.gov/ct2/show/NCT03111992) suggest that Novartis is still interested in this molecule. Meanwhile, combination studies of Birinapant (SMAC mimetic) with Keytruda for MSS- CRC (Phase 2) and Entevir/Tenofovir for viral hepatitis B (Phase 1) were terminated due to futility analysis of data [78] and cranial nerve palsies [108], respectively (Table 2).

\section{Inhibition on IKK Complex in NF- $\mathrm{kB}$ Pathway}

\subsection{IKK $\alpha$ and IKK $\beta$ Inhibitors}

During the stimulation of the canonical NF-KB pathway, IKK complex, made of IKK $\alpha$ and IKK $\beta$ as kinase subunit and IKK $\gamma$ as regulatory subunit, is activated [109]. Activation of the IKK complex plays a central role in the canonical NF-KB pathway. The signaling cascade begins through the activation of receptors such as IL1R, TNFR, TLR, TCR and BCR at the cell membrane level. Once activated, these receptors and their associated protein complexes come together and percolate into intracellular signaling networks by utilizing adaptor protein interactions, protein phosphorylation, non-degradative ubiquitination and other signal-transducing mechanisms to activate this pathway. Evidence shows that diverse signaling cascades from various cellular receptors converge to activate TAK1, which then phosphorylates IKK $\beta$ at T-loop serine residues, S177 and S181, resulting in the activation of the IKK complex. IKK complex eventually phosphorylates IKB leading to p65:p50 release $[33,110,111]$. For the non-canonical pathway IKK $\alpha$ plays an indispensable role. Once TNFRSF receptor (RANK, BAFFR (B-cell activating factor receptor), CD40, TWEAK (Tumor necrosis factor-like weak inducer of apoptosis), and LT $\beta$ ) is activated in the non-canonical NF- $\mathrm{KB}$ pathway, NIK levels are stabilized. 
NIK phosphorylates IKK $\alpha$ homodimer on T-loop serine residues, S176 and S180. This activates IKK $\alpha$ complex and leads to P100 processing to p52 through partial ubiquitination [14,112]. Thus, IKK $\alpha$ and IKK $\beta$ play a critical role in the NF- $\mathrm{KB}$ pathway and their inhibitors would effectively block the whole pathway. It is for the same reason that no IKK $\alpha$ or IKK $\beta$ inhibitor has cleared phase 2 studies [21] (Table 3). SAR-113945, an IKK $\alpha / \beta$ small molecule inhibitor developed by Sanofi and MLN-0415 by Millennium Pharmaceuticals did not meet primary endpoints of phase 2 and safety profile of phase 1, respectively. Also, Merck's AS-602868 and Leo Pharma's CHS-828 were also discontinued due to unknown reason (Table 3). Prescott et. al. [109] has discussed these failures and reasoned that the development of more selective non-ATP competitive inhibitors, usage of isoform-specific readouts to differentiate role of IKK $\alpha$ vs. IKK $\beta$ in cellular activity and appropriate application of therapeutics should lead to more clinical success.

Sulfasalazine, a disease-modifying anti-rheumatic drug (DMARD) launched for RA and other autoimmune disorders, was also reported to directly inhibit IKK $\alpha$ and IKK $\beta$ by antagonizing ATP binding [113]. Anti-inflammatory and immunosuppressive effects of Sulfasalazine are attributed to the suppression of NF-kB activation via inhibition of IKKs. Many nonsteroidal anti-inflammatory drugs (NSAID) like Aspirin and Salicylate are inhibitors of NF-KB pathway [114]. They inhibit ATP binding to IKK $\beta$ and thus prevent activation \& translocation of NF- $\mathrm{KB}$ to the nucleus. Salsalate, the pro-drug of salicylate, is marketed for inflammatory and non-inflammatory disorders. Moreover, in diabetes, since the NF-KB pathway serves as a potential target, clinical trials to test for the efficacy of salsalate in reducing glycemia and insulin resistance diabetes were undertaken successfully [115].

\subsection{Inhibitor of Nuclear Factor Kappa-B Kinase Subunit Gamma (IKK $\gamma$ ) Inhibitors}

IKK $\gamma$, also known as NF- $\mathrm{KB}$ essential modulator (NEMO), is the regulatory subunit of the IKK complex. Its inhibition or inhibition of its binding to the complex renders IKK inactive. Unlike inhibition of IKK $\alpha$ or IKK $\beta$ that results in gross toxicity, inhibition of IKK $\gamma$ only affects the NF- $k B$ pathway mediated by IKK complex and will not inhibit the standalone activities of IKK $\alpha$ or IKK $\beta$ or the non-canonical pathway. NEMO Binding Domain (NBD) peptide was developed to inhibit binding of NEMO to IKK $\alpha$ or IKK $\beta$ and reportedly inhibits only the inflammation induced NF- $\kappa B$ activation pathway, with little or no effect on the basal NF- $\mathrm{kB}$ activity $[21,116]$. Unfortunately, due to the low plasma stability and druggability issues of this peptide, it was never taken to clinic. Even modifications of NBD [117] such as covalently linking it to either cell penetrating peptides or Drosophila Antennapedia domain or even macrocyclization to make it into a proteolytically stable bicyclic peptide could not take any NEMO inhibitor to clinical trials. To succeed, IKK $\gamma$ inhibitors have to overcome the proteasomal degradation and address drug delivery issues.

\subsection{IKKe and Tank Binding Kinase 1 (TBK1) Inhibitors}

IKK $\varepsilon$ share $67 \%$ sequence identity with TBK1 and collectively regulates activation of interferon regulatory factor (IRF)-family factors (IRF3/5/7) by Rig-I like receptors and other receptors [118]. Phosphorylation of IRF3 has subsequently led to expression of interferon-stimulated genes (ISGs). TBK1 also phosphorylates STING (stimulator of interferon genes) and makes it more accessible for binding to IRF3. To date, no molecule that was specifically designed to inhibit IKK $\varepsilon$ or TBK1 has reached clinic trials. However, a number of small molecules that have been approved or explored for different mechanism of actions, were later found to inhibit IKK $\varepsilon / T B K 1$ [119]. Amlexanox (Histamine and Leukotriene inhibitors-approved for Asthma), BX-795 (three phosphoinositide dependent protein kinase 1 inhibitors), Momelotinib (JAK inhibitor) are some of the examples. These compounds led to specific inhibitors like MPI-0485520 (developed by Myrexis) and DMXD-011 (by Domainex) but they were not taken beyond preclinical studies. Preclinical research for their use as a synthetic lethal target and their combination therapy are being explored and we may see more molecules in clinical trial. 
Table 3. Clinical small molecules inhibitors targeting IKK complex in NF- $\mathrm{kB}$ pathway.

\begin{tabular}{|c|c|c|c|c|c|}
\hline Drug & Originator/Developer & Stage & Indication & Trail No. & Other Information \\
\hline \multicolumn{6}{|c|}{ IKK $\alpha / \beta$ Inhibitors } \\
\hline CHS-828 & Leo Pharma & Discontinued at phase 2 & Solid tumor & NCT00003979 & $\begin{array}{l}\text { - Originally Nicotinamide phosphoribosyl } \\
\text { transferase (NAMPT) inhibitor. } \\
\text { Dose-limiting toxicities; thrombosis, } \\
\text { thrombocytopenia, esophagitis, diarrhea, and } \\
\text { constipation [120]. }\end{array}$ \\
\hline \multirow{2}{*}{$\begin{array}{c}\text { IMD-1041 } \\
\text { (Pro-drug of IMD-0354) }\end{array}$} & \multirow{2}{*}{$\begin{array}{l}\text { Institute of Medicinal } \\
\text { Molecular Design }\end{array}$} & Phase 2 & COPD & NCT00883584 & \multirow{2}{*}{$\begin{array}{l}\text { - No further development reported for COPD. } \\
\text { - Clinical phases for other indication unknown. }\end{array}$} \\
\hline & & NA & $\begin{array}{c}\text { Age-related macular } \\
\text { degeneration, DM, Glaucoma, PF }\end{array}$ & NA & \\
\hline \multirow[b]{2}{*}{ SAR-113945 } & \multirow[b]{2}{*}{ Sanofi } & Discontinued at Phase 2 & OA & NCT01598415 & \multirow{2}{*}{$\begin{array}{l}\text { - } \quad \text { SAR-113945 gave as intra-articular injection. } \\
\text { Phase } 1 \text { studies was promising but Phase } 2 \mathrm{~b} \\
\text { proof-of-concept study failed to show efficacy } \\
\text { in a larger patient sample size [121]. }\end{array}$} \\
\hline & & Discontinued at Phase 1 & OA & $\begin{array}{l}\text { NCT01113333, } \\
\text { NCT01463488, } \\
\text { NCT01511549 }\end{array}$ & \\
\hline MLN-0415 & Millennium Pharmaceuticals & Discontinued at Phase 1 & Arthritis, Inflammation, MS & NA & Unfavorable safety profile in Phase 1. \\
\hline \multirow{2}{*}{ VGX-1027 } & \multirow{2}{*}{ VGX Pharmaceuticals } & Phase 1 & Healthy subjects (RA) & NCT00627120 & \multirow{2}{*}{ No development reported for RA or other diseases } \\
\hline & & Phase 1 & Healthy subjects (RA) & NCT00760396 & \\
\hline \multirow{2}{*}{$\begin{array}{l}\text { Teglarinad Chloride } \\
\text { (EB-1627; GMX1777) }\end{array}$} & \multirow{2}{*}{ Leo Pharma } & Phase 1 & Malignant melanoma & NCT00724841, & $\begin{array}{l}\text { Multi dose study conducted with combination of } \\
\text { Temozolomide. }\end{array}$ \\
\hline & & Phase 1 & Lymphoma, Solid tumors & NCT00457574 & Single therapy was performed. \\
\hline AS-602868 & Merck & Discontinued at Phase 1 & Hematological malignancies & NA & Also, inhibit FLT3. \\
\hline
\end{tabular}

Abbreviations: COPD—chronic obstructive pulmonary disease; DM—Diabetes mellitus; FLT3—FMS-like tyrosine kinase 3; MS—Multiple sclerosis; NA—not available; OA—osteoarthritis; PF-Pulmonary fibrosis; RA—rheumatoid arthritis. 


\subsection{NF-אB Inducing Kinase (NIK) Inhibitors}

NIK is the master regulator of non-canonical NF-KB pathway [18]. It phosphorylates IKK $\alpha$ and that subsequently initiates $\mathrm{p} 100-\mathrm{p} 52$ processing. Mature $\mathrm{p} 52$ heterodimerizes with RelB and translocate to the nucleus to regulate gene transcription. Stabilization of NIK and its accumulation is a hallmark in many cancers. Further, the relevance of the non-canonical NFKB pathway in B-cell maturation makes NIK a very desirable target. Many research groups, including pharmaceutical companies like Amgen, Genentech published multiple patents with subnanomolar enzymatic activity and even appreciable in vivo efficacy. However, none of them made it to clinical trials. The closest one was Tracon pharmaceutical's TRC-694 (JNJ-64290694 in-licensed from Janssen) that they were planning to take into phase 1 proof-of-concept study for patients with hematologic malignancies, including myeloma. Last year they returned the rights to Janssen after completion of the pre-clinical study and no further development were reported [122]. Most scaffolds, for potent NIK inhibition have an alkyne side chain that may be associated with some toxicity, but structurally different compounds published [123] by Johnson not being considered for clinical trial negate this theory. The probable biology of NIK and its exact role in disease are still grey areas and appropriate indication or relevant combination needs to be worked out for clinical consideration.

\section{Molecules that Inhibit Ubiquitin-Proteasome System (UPS)}

The relationship between protein homeostasis and proteolysis plays a key role for regulation of many pathways including NF-KB pathway. UPS is one of the main mechanisms [124] of intracellular protein degradation that is also important for activating protein by partial degradation or post-translational modification. Proteolysis is highly controlled [125] by multiple steps, both at the proteasome end and the targeted protein for degradation, to avoid non-specific degradation. It involves diverse enzymes that render further specificity to the proteolytic degradation. Some proteins need not be ubiquitinated before degradation like conversion of p105 to p50 in canonical NF- $\mathrm{kB}$ pathway or in post-translational processing. Similarly, some proteins also undergo nondestructive polyubiquitination in the signaling cascade.

In UPS, covalent attachment of multiple ubiquitin molecules with substrate proteins are intended for proteasomal degradation, which gives a recognition signal for the $26 \mathrm{~S}$ proteasome. The two distinct and successive steps are involved in the degradation of protein substrates in this pathway, the first one is the ubiquitin conjugation cascade and the second one is destruction process mediated by proteasome core. The former one encompasses the enzymes required for activation, conjugation, and ligation of ubiquitin to protein substrates and the later one takes ubiquitinated proteins to their final fate. Ubiquitination happens typically with three sets of enzymes such as ubiquitin activating enzymes (E1), ubiquitin conjugating enzymes (E2), and ubiquitin ligases (E3) [126,127].

In the first step, E1 activates this cascade through adenylation of the ubiquitin at the terminal carboxyl group of Glycine involves the hydrolysis of ATP to PPi. Eventually, E1 covalently links to ubiquitin via a high-energy thioester linkage. As a second activity, the activated ubiquitin is transferred from E1 to conjugating enzyme E2. On the final step, typically ubiquitin to the protein substrate requires E3 or ligase via forming an amide isopeptide bond between the carboxyl group of Glycine of ubiquitin and amino group of the protein substrate's internal Lys residue. After the mono-ubiquitination, subsequent ubiquitination conjugation cascade happens between glycine residue of ubiquitin and lysine residue of ubiquitin that is already conjugated to the protein substrate called as poly-ubiquitination [128].

Protein substrate modification in UPS comprises two types of ubiquitin chains, single linkage types are called homotypic chains (mono and polyubiquitylation), where heterotypic chains comprise mixed linkages within the same polymer or one ubiquitin molecule has two or more ubiquitylated sites (mixed and branched ubiquitylation). Proteins can be modified at one lysine residue with either a single ubiquitin molecule or ubiquitin polymers called mono and polyubiquitylation respectively, multiple lysine residues modified with a single ubiquitin known as multiple mono ubiquitylation $[126,129]$. 
Heterotypic chains are classified into mixed chains or branched chains. In mixed chains, each ubiquitin is modified only once by another ubiquitin, wherein branched chains, each ubiquitin can be modified by two or more ubiquitin molecules. Due to the huge number of possible conjugate combinations in branched chains, it is affecting different signaling pathways and K48/K63 is one of the most studied branched chains, implicated in NF-KB signaling and apoptosis [128-130].

\subsection{Proteasome Inhibitors}

In the canonical and non-canonical NF- $\mathrm{kB}$ pathways, proteolytic degradation modulates multiple steps [125]. In the canonical pathway, proteasomal degradation of I $\kappa B$ leads to release of active NF- $\kappa B$ complex (p50/RelA). In the non-canonical pathway, NIK/IKK $\alpha$ mediated phosphorylation of p100 converts it into $\mathrm{p} 52$ through partial proteolysis. Thus, these can be targeted for therapeutic intervention and proteasome inhibitors can be used to effectively modulate the NF-KB pathway (Table 4). On the other hand, the critical role played by the proteasomes in fundamental cellular processes, may also lead to target related ADR.

The first clinically approved small molecule proteasome inhibitor, Bortezomib with boronic acid functionality, is a slow reversible inhibitor of the $20 \mathrm{~S}$ proteasome [131]. It is currently marketed for MCL, MM, and WM and registered for B-cell lymphoma (BCL). It is undergoing phase 3 for DLBCL and relapsed, or relapsed and refractory multiple myeloma (RRMM) (Table 4) [132]. The poor tissue penetration and high plasma clearance made it a poor choice for treating solid tumors [133]. Development of resistance and peripheral neuropathy are serious limitations of this first-in-class drug [131]. Ixazomib, a boronic ester pro-drug, was the first orally administered drug [134] approved by the FDA in 2015. Though it is also a reversible inhibitor, unlike Bortezomib, it had fast disassociation rate when bound to RBC and had better tissue distribution. It was developed by Takeda and received orphan drug status for MM and amyloidosis (Table 4). Ixazomib was approved in combination with lenalidomide and dexamethasone for RRMM [135]. Last year, phase 3 trial of combination with dexamethasone was discontinued, as it did not demonstrate significant improvement in overall hematologic response compared with standard therapy in patients with relapsed/refractory systemic light-chain amyloidosis [136]. It was also discontinued for solid tumors (Table 4).

The second generation Carfilzomib has an epoxyketone group, making it an irreversible inhibitor of $20 \mathrm{~S}$ proteasome. It has received orphan drug status for MM and WM. The FDA approved it in 2012 for MM patients who has already received other therapies (Table 4) [137]. Amgen recently also completed phase 2 trial for MM as second-line or greater combination therapy with dexamethasone. Unlike bortezomib, patients using carfilzomib had less severe peripheral neuropathy [137], but showed varying degree of adverse cardiovascular events [138], due to its effects on myocardial proteasomes (Table 4). There were reports $[137,139]$ of severe acute kidney injury and rhabdomyolysis in patients with additional complication. To overcome intravenous administration of Carfilzomib, orally bioavailable Oprozomib was developed. Oprozomib received orphan drug status for MM and WM [140] (Table 4). Last year Amgen and Onyx Pharmaceuticals completed phase 1b/2 trial for MM and hematological malignancies respectively. Earlier, Amgen reported phase 1b/2 combination study with melphalan and prednisone in transplant ineligible patients with newly diagnosed MM [140].

Marizomib is a naturally occurring broad-spectrum proteasome inhibitor isolated from the marine actinomycetes Salinispora tropica a cytotoxic constituent called salinosporamide A. It is reported to be less toxic, more efficient and structurally different from other approved proteasome inhibitors (Table 4) [141]. Celgene explored this for the treatment of RRMM and demonstrated clinically relevant activity, good tolerability with no severe peripheral neuropathy or hematologic toxicity in phase 1 trial. Phase 2 trial for RRMM was also encouraging and as it can pass through the blood-brain barrier. This initiated phase 3 for the potential treatment for glioblastoma in combination with temozolomide-based radiochemotherapy [142]. Disulfiram, launched in 1951 to support the treatment of chronic alcoholism, showed anticancer activity, possibly due to the disruption of the NF- $\mathrm{kB}$ pathway 
by proteasomal inhibition $[143,144]$. It received orphan drug status for glioblastoma and is currently in phase 2 trials for pancreatic cancer as a second-line of therapy (Table 4).

\subsection{Deubiquitination (DUB) Inhibitors}

DUB inhibitors are also being explored as therapeutic interventions in specific cancers. DUB is accomplished by proteases that can cleave the isopeptide bond formed during ubiquitination. Vivolux identified a novel Ubiquitine Specific Proteases 14 (USP14) specific inhibitor, VLX1570, and it has entered phase 1/2 trial for MM (Combination therapy, Second-line therapy or greater), but was terminated due to dose-limiting toxicity (https://clinicaltrials.gov/ct2/show/NCT02372240) (Table 4). Multiple groups like Nynex Therapeutics, AbbVie, Ubiquigent have reported promising DUB inhibitors at the preclinical stage, but as of date, none of them have reached clinical trials.

\subsection{NAE (NEDD8 Activating Enzyme) Inhibitors}

NAE is a heterodimeric molecule that catalyzes the formation of neural precursor cell expressed, developmentally down-regulated 8 (NEDD8)—adenosine monophosphate (AMP). NEDD8 is a ubiquitin-like protein that modifies cellular targets in a pathway that is parallel to but distinct from ubiquitin modification [154]. NEDDylation is crucial for the activation of Cullin-RING-E3 ubiquitin ligases that are critical for proteasome-mediated protein degradation. Thus, NAE is a desirable target for intervention as it acts upstream of proteasome and catalyzes the first step in the NEDDylation pathway [155]. Unfortunately, this broad intervention may have associated side effects, and one needs to weigh the benefits to the toxicity ratio before taking them to the clinic.

Pevonedistat, first-in-class NAE inhibitor from Millennium Pharmaceuticals, is an AMP mimetic that forms stable covalent adducts with NEDD8 in NAE catalytic pocket and prevents subsequent NAE reaction. It has received orphan drug status for AML and Myelodysplastic syndromes (MDS). Pevonedistat combination study with Azacitidine was terminated in AML patient, but the preliminary results encouraged Takeda to consider phase 2 trial for high risk MS. They also explored the same combination in phase 3 study for low-risk AML, high-risk Chronic myelomonocytic leukemia (CMML), and high-risk MDS [156] (Table 4). Though, due to serious toxicity at higher doses, pevonedistat dose beyond $100 \mathrm{mg} / \mathrm{m}^{2}$ is not being considered for further investigation [153]. Takeda had one more Millennium molecule TAK-243 in phase 1 for relapsed or refractory AML, refractory MDS, and CML (https:/clinicaltrials.gov/ct2/show/NCT03816319), but the studies were probably discontinued. Similarly, TAS-4464 by Taiho Pharmaceutical was also discontinued in phase 1 for HM and solid tumors, due to business reasons (https://clinicaltrials.gov/ct2/show/NCT02978235). 
Table 4. Clinical small molecules inhibitors targeting Ubiquitin-Proteasome System (UPS) in NF-kB pathway.

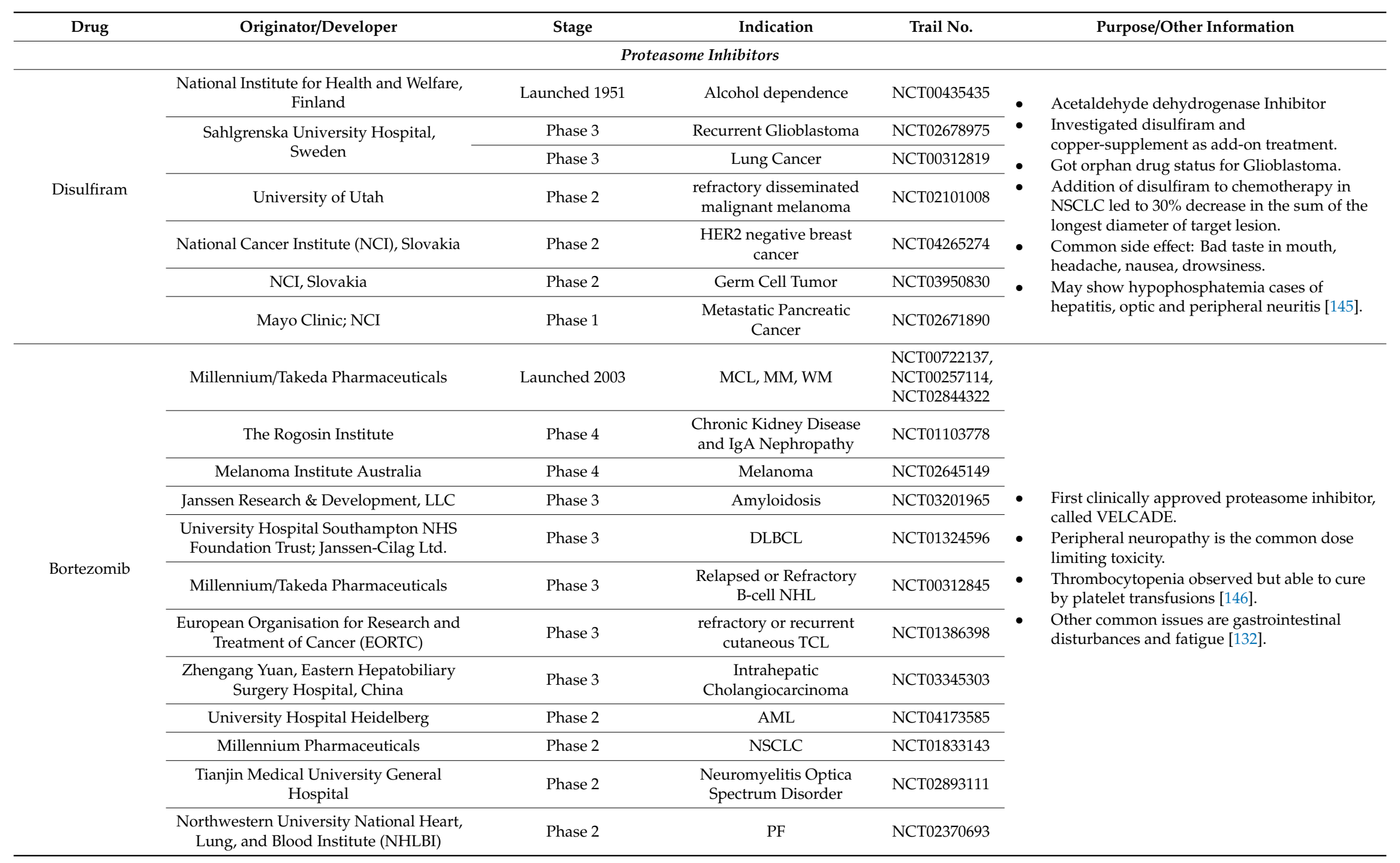


Table 4. Cont.

\begin{tabular}{|c|c|c|c|c|c|}
\hline Drug & Originator/Developer & Stage & Indication & Trail No. & Purpose/Other Information \\
\hline & $\begin{array}{l}\text { Sidney Kimmel Cancer Center at Thomas } \\
\text { Jefferson University }\end{array}$ & Phase 2 & GVHD & NCT00408928 & \\
\hline \multirow{6}{*}{ Ixazomib } & Millennium/Takeda Pharmaceuticals & Launched at 2015 & MM & NCT03173092 & \multirow{6}{*}{$\begin{array}{l}\text { - First oral proteasome inhibitor, marketed } \\
\text { as Ninlaro. } \\
\text { "Breakthrough Therapy" status from the U.S.- } \\
\text { FDA for relapsed and/or refractory } \\
\text { AL amyloidosis. } \\
\text { - TEAE: thrombocytopenia, peripheral edema, } \\
\text { peripheral neuropathy, nausea, diarrhea, } \\
\text { constipation, vomiting, and back pain } \\
\text { [135,147]. }\end{array}$} \\
\hline & Takeda Pharmaceuticals & Phase 2 & $\begin{array}{c}\text { Immune } \\
\text { Thrombocytopenia and } \\
\text { Autoimmune Hemolytic } \\
\text { Anemia }\end{array}$ & NCT03965624 & \\
\hline & Millennium/Takeda Pharmaceuticals & Phase 2 & $\begin{array}{l}\text { Myeloid and Lymphoid } \\
\text { Hematologic Malignancy }\end{array}$ & NCT03082677 & \\
\hline & Takeda Pharmaceuticals & Phase 2 & MCL & NCT03616782 & \\
\hline & Millennium Pharmaceuticals & Phase 2 & $\begin{array}{l}\text { Kidney Diseases andEnd } \\
\text { stage Renal Disease }\end{array}$ & NCT03213158 & \\
\hline & Millennium Pharmaceuticals/NCI & Phase 2 & B-cell NHL & NCT02339922 & \\
\hline \multirow{7}{*}{$\begin{array}{l}\text { Carfilzomib } \\
\text { (Kyprolis) }\end{array}$} & $\begin{array}{l}\text { Proteolix/Onyx Pharmaceuticals, AbbVie, } \\
\text { Genentech \& others, Amgen }\end{array}$ & Launched at 2012 & $\mathrm{MM}$ & NCT03934684 & \multirow{7}{*}{$\begin{array}{l}\text { - Hematologic TEAE: thrombocytopenia } \\
\text { and anemia. } \\
\text { - Nonhematologic TEAE: upper respiratory tract } \\
\text { infections, fatigue, nausea, dyspnea, diarrhea, } \\
\text { and pyrexia }[148,149] \text {. }\end{array}$} \\
\hline & Onyx Therapeutics, Inc & Phase 2 & MCL & NCT02042950 & \\
\hline & $\begin{array}{l}\text { SCRI Development Innovations, LLC, } \\
\text { Amgen }\end{array}$ & Phase 2 & Neuroendocrine Cancer & NCT02318784 & \\
\hline & Onyx Therapeutics, Inc. & Phase 2 & $\begin{array}{l}\text { Refractory Renal Cell } \\
\text { Carcinoma }\end{array}$ & NCT01775930 & \\
\hline & Amgen & Phase 2 & $\begin{array}{c}\text { Metastatic } \\
\text { Castration-resistant } \\
\text { Prostate Cancer }\end{array}$ & NCT02047253 & \\
\hline & $\begin{array}{l}\text { Fred Hutchinson Cancer Research } \\
\text { Center, NCI }\end{array}$ & Phase 2 & Chronic GVHD & NCT02491359 & \\
\hline & M.D. Anderson Cancer Center; Amgen & Phase 1 & MCL, TCL, DLBCL & NCT01926665 & \\
\hline \multirow{4}{*}{ Marizomib } & Nereus Pharmaceuticals/Celgene & Phase 3 & Glioblastoma & NCT03345095 & \multirow{4}{*}{$\begin{array}{l}\text { TEAE: fatigue, nausea, diarrhea, vomiting, } \\
\text { constipation, dizziness, infusion site pain, back } \\
\text { pain, anorexia, anemia and dyspnea. } \\
\text { Unlike bortezomib, did not induce the limiting } \\
\text { toxicities viz. peripheral neuropathy, } \\
\text { neutropenia and thrombocytopenia [150]. }\end{array}$} \\
\hline & Celgene & Phase 2 & MM & NCT00461045 & \\
\hline & $\mathrm{NCI}$ & Phase 2 & Anaplastic Ependymoma & NCT03727841 & \\
\hline & Celgene & Phase 1 & $\begin{array}{l}\text { NSCLC, Pancreatic } \\
\text { Cancer, Melanoma, } \\
\text { Lymphoma, MM }\end{array}$ & NCT00667082 & \\
\hline
\end{tabular}


Table 4. Cont.

\begin{tabular}{|c|c|c|c|c|c|}
\hline Drug & Originator/Developer & Stage & Indication & Trail No. & Purpose/Other Information \\
\hline \multirow{4}{*}{ Oprozomib } & Onyx Pharmaceuticals & Phase $1 / 2$ & $\mathrm{R}$ and/or R MM & NCT01832727 & \multirow{4}{*}{$\begin{array}{l}\text { - TEAE: Hypotension, thrombocytopenia, } \\
\text { anemia and diarrhea [151]. } \\
\text { - Well tolerated in combinations with } \\
\text { pomalidomide and dexamethasone. }\end{array}$} \\
\hline & Amgen & Phase $1 / 2$ & Advanced HCC & NCT02227914 & \\
\hline & Amgen & Phase $1 / 2$ & MM, WM & NCT01416428 & \\
\hline & Amgen & Phase 1 & Solid Tumors & NCT01129349 & \\
\hline \multicolumn{6}{|c|}{ Deubiquitination (DUB) inhibitors } \\
\hline VLX1570 & Vivolux, Mayo Clinic & Phase $1 / 2$ & $\mathrm{MM}$ & NCT02372240 & $\begin{array}{c}\text { Death of } 2 \text { patients receiving two doses at } 1.2 \mathrm{mg} / \mathrm{kg} \\
\text { due to fatal pulmonary toxicity [152]. }\end{array}$ \\
\hline \multirow{5}{*}{ Pevonedistat } & Millennium Pharmaceuticals & Phase 3 & AML & NCT03268954 & \multirow{5}{*}{$\begin{array}{l}\text { DLT: Transaminase elevation, orthostatic } \\
\text { hypotension, rash and elevated alanine } \\
\text { transaminase [153]. } \\
\text { - Cardiac failure and multiorgan failure } \\
\text { observed at dose of } 147 \mathrm{mg} / \mathrm{m}^{2} \text {. } \\
\text { - No DLT at doses }<50 \mathrm{mg} / \mathrm{m}^{2} \text {. }\end{array}$} \\
\hline & NCI & Phase 2 & $\begin{array}{c}\text { Metastatic } \\
\text { Cholangiocarcinoma, } \\
\text { HCC }\end{array}$ & NCT04175912 & \\
\hline & $\begin{array}{l}\text { University of Michigan Rogel Cancer } \\
\text { Center }\end{array}$ & Phase 2 & NSCLC & NCT03228186 & \\
\hline & $\mathrm{NCI}$ & Phase 2 & $\begin{array}{l}\text { Myeloproliferative } \\
\text { Neoplasm }\end{array}$ & NCT03238248 & \\
\hline & Millennium Pharmaceuticals & Phase 1 & $\begin{array}{l}\text { Advanced Solid Tumors } \\
\text { and Neoplasms }\end{array}$ & NCT03057366 & \\
\hline TAS-4464 & Taiho Oncology & Phase 1/2; Terminated & $\mathrm{MM}, \mathrm{HNL}$ & NCT02978235 & As of Dec 2019, discontinued for most indications. \\
\hline \multirow{2}{*}{ TAK-243 } & Takeda Pharmaceuticals & Phase 1 & $\begin{array}{c}\text { Myelodysplastic } \\
\text { Syndrome, AML, CMML }\end{array}$ & NCT03816319 & \multirow{2}{*}{$\begin{array}{l}\text { Phase } 1 \text { trial for AML, Myelodysplastic syndrome } \\
\text { and CMML initiated in May } 2019 .\end{array}$} \\
\hline & Millennium Pharmaceuticals & Phase 1 ; terminated & $\begin{array}{l}\text { Advanced Malignant } \\
\text { Solid Tumors }\end{array}$ & NCT02045095 & \\
\hline
\end{tabular}

Abbreviations: AML—acute myeloid leukemia; CMML—chronic myelomonocytic leukemia; DLBCL—diffuse large B-cell lymphoma; DLT—dose limiting toxicity; GVHD—graft versus host disease; HCC—hepatocellular carcinoma; MCL—Mantle cell lymphoma; MM-Multiple myeloma; NHL—Non-Hodgkin lymphoma; NSCLC—non-small cell lung cancer; PF—Pulmonary Fibrosis; RRWM—relapsed and refractory Multiple myeloma; TCL—T-cell lymphoma; TEAE—Treatment-emergent adverse effects; WM—Waldenstrom macroglobulinemia. 


\section{Molecules Inhibiting Nuclear Translocation, DNA Binding and Transcriptional Activation of NF- $\mathrm{KB}$}

Nuclear import and cytoplasmic export of NF-KB happens through p65 shuttling between cytoplasm and nucleus. As the shuttling is essential to sustain all p65 mediated transcriptional programs and as it is implicated in various disease conditions such as cancer, inflammatory, and autoimmune diseases, it becomes an attractive therapeutic target. After the release of $\mathrm{p} 65$ from IkB by stimulation, arginine and lysine-rich nuclear localization signals (NLS) of p65 interacts first with importin $\alpha$ and later with importin $\beta$ to form a heterodimer. Ferrying of trimeric cytosolic NLS (cNLS)/importin $\alpha / \beta$ protein complex into the nucleus is facilitated through importin $\beta$ interaction with nuclear pore complexes (NPCs). NF-kB activation is one of the highly controlled pathways, following the translocation of p65, the increased transcriptional activity eventually results in a negative feedback oscillatory loop for p65 export from the nucleus [157-159].

The activated $p 65$ interacts with DNA and stimulates the synthesis of IкB $\alpha$ mRNA and increase the nuclear concentration of IкB $\alpha$. The increased I $\mathrm{K} B \alpha$ protein binds and exports with free p65 and DNA detached $p 65$. This negative feedback regulation is highly controlled by IкB $\beta$ and IкB $\gamma$. IкB $\alpha$ protein composes a nuclear export regulatory domain contains leucine-rich nuclear export signal (NES) at $\mathrm{N}$ terminal region that plays a pivotal role for cytoplasmic localization of $\mathrm{p} 65$. The export of $\mathrm{p} 65$ happens via the CRM1 (chromosome region maintenance 1/exportin1/Exp1/Xpo1)-dependent pathway upon the interaction of CRMI and I $\kappa \mathrm{B} \alpha$ protein at leucine-rich NES domain. CRM1 is an export receptor, facilitates the transport of large macromolecules including RNA and protein from the nuclear membrane to the cytoplasm. CRM1 binds the Ran protein bound to GTP, allowing for a conformational change that facilitates cargo protein to nuclear export (Figure 3) [157-159].

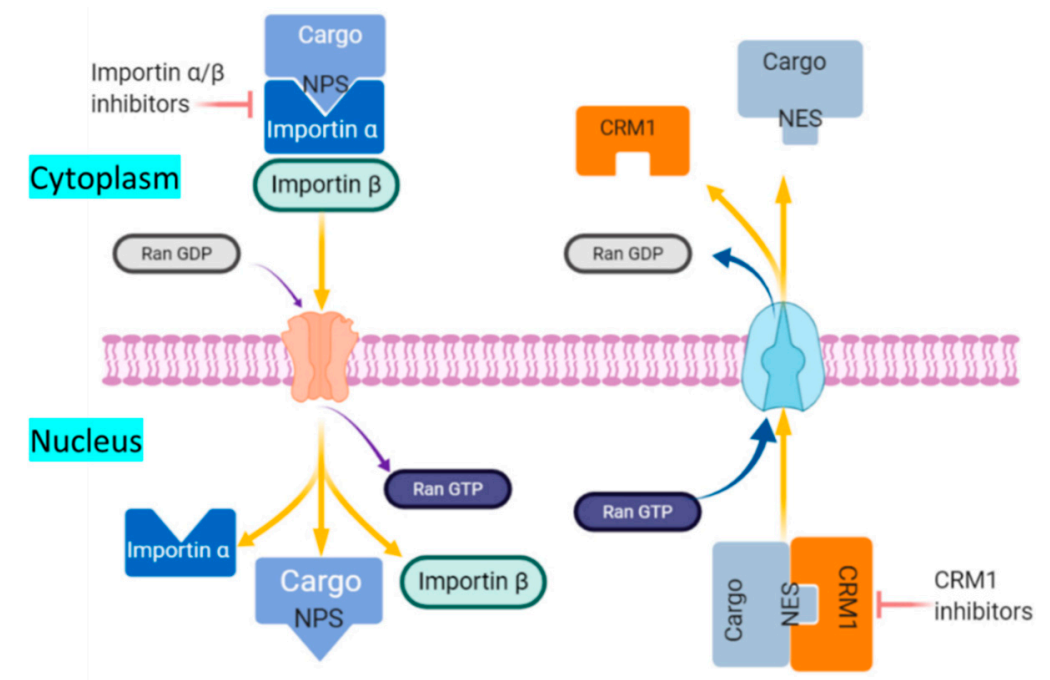

Figure 3. p65 shuttling and the current therapeutic targets explored in the pathway. After ubiquitination $\mathrm{IkB}$, translocation of p65/p50 (Cargo) happens via arginine and lysine-rich NLS (Nuclear localization signals) of p65 interaction with importin $\alpha / \beta$ heterodimer. This trimeric protein complex (cNLS/importin $\alpha / \beta$ protein) ferrying into the nucleus is facilitated through importin $\beta$ interaction with nuclear pore complexes (NPCs). Whereas export of p65 via the CRM1-dependent pathway upon interaction with leucine-rich NES. CRM1 is an export receptor, facilitates the transport of large macromolecules including RNA and protein from the nuclear membrane to the cytoplasm. CRM1 binds the Ran protein bound to GTP, allowing for a conformational change that facilitates cargo protein to nuclear export. Nuclear import and export inhibitors preclude the p65 shuttling via NLS and NES, respectively.

The stimuli induced p65 activation is transient, however, it upregulates transactivation of target genes of diverse activities such as cell proliferation and inflammatory cytokine release. Signals between $\mathrm{p} 65$ and transcription factors facilitate controlled and efficient transactivation. Further, 
various post-translational modifications (PTM) including ubiquitination, acetylation, methylation, phosphorylation, and sumoylation of p65 play a vital role in the NF- $\kappa B$ activation outcomes. DNA:p65 binding determines NF- $\mathrm{kB}$ activation and it is affected interactions with coactivators and corepressors as well as p65 termination [112,160].

Phosphorylation of $\mathrm{p} 65$ has also been implicated in NF- $\mathrm{kB}$ regulation and involves mainly serine and threonine sites. The phosphorylation sites are mostly located in the Rel homology domain (RHD) and the transactivation domains (TAD) and the activation results in either increased or decreased transcriptional activity. Histone acetyltransferases (HATs) and histone deacetylases (HDACs) regulate the acetylation of $\mathrm{p} 65$ at lysine sites via acetylation and deacetylation respectively. Lysine acetylation of p65 is a reversible process and it depends on coactivators such as p300 and CREB binding protein (CBP) [161]. Tip60 (HIV Tat-interacting protein 60), a coactivator of NF-kB p65, enhances acetylation of Lys310 and upregulate p65 transcriptional activity through PPI. Moreover, Tip60 binds DNA prior to p65 and potentially modulates other cofactors interactions with p65 [162]. The acetylation of specific lysine residue Lys122 [163] and Lys123 decreases DNA binding of NF-kB p65 whereas Lys221 [38] and Lys218 enhances the DNA binding of NF- $\mathrm{kB}$ p65. Lys310 acetylation is recognized by the two bromodomains of Brd4, which recruits activated CDK9 to phosphorylate RNA polymerase II for the transcription of a subset of NF- $\mathrm{kB}$ target genes [28,164].

\subsection{Nuclear Export Inhibitors}

Leptomycin B (LMB), an irreversible CRM1 inhibitor covalently binds to cysteine 528 and directly blocks its interaction with the NES. LMB was tested for advanced refractory cancer, but was discontinued due to significant systemic toxicity and limited efficiency at phase 1. Later on, Karyopharm developed LMB analogue KOS-2464, but it has not been tested in a clinical setting so far [165-167]. Synthetic CRM1 inhibitor (CBS9106) blocks the nuclear export by inducing CRM1 degradation via Neddylation pathway and at present, it is in phase1 trial for metastatic solid tumor. Structure-based drug design led to the further development of CRM1 small molecule inhibitors called as selective inhibitors of nuclear export (SINE) includes Selinexor (KPT-330), Verdinexor (KPT-335) and Eltanexor (KPT-8602) and these are orally bioavailable and highly selective. They are currently in clinical trials for various cancer conditions as standalone or in combination with other drugs. They are also found to be potential antiviral agents against various influenza strains and respiratory syncytial virus. Selinexor (KPT-330) got FDA approval in July 2019 for RRMM and is currently also taken into COVID-19 clinical trial [168-170] (Table 5). 
Table 5. Clinical small molecules inhibitors targeting nuclear translocation, DNA binding, and transcriptional activation of NF-kB.

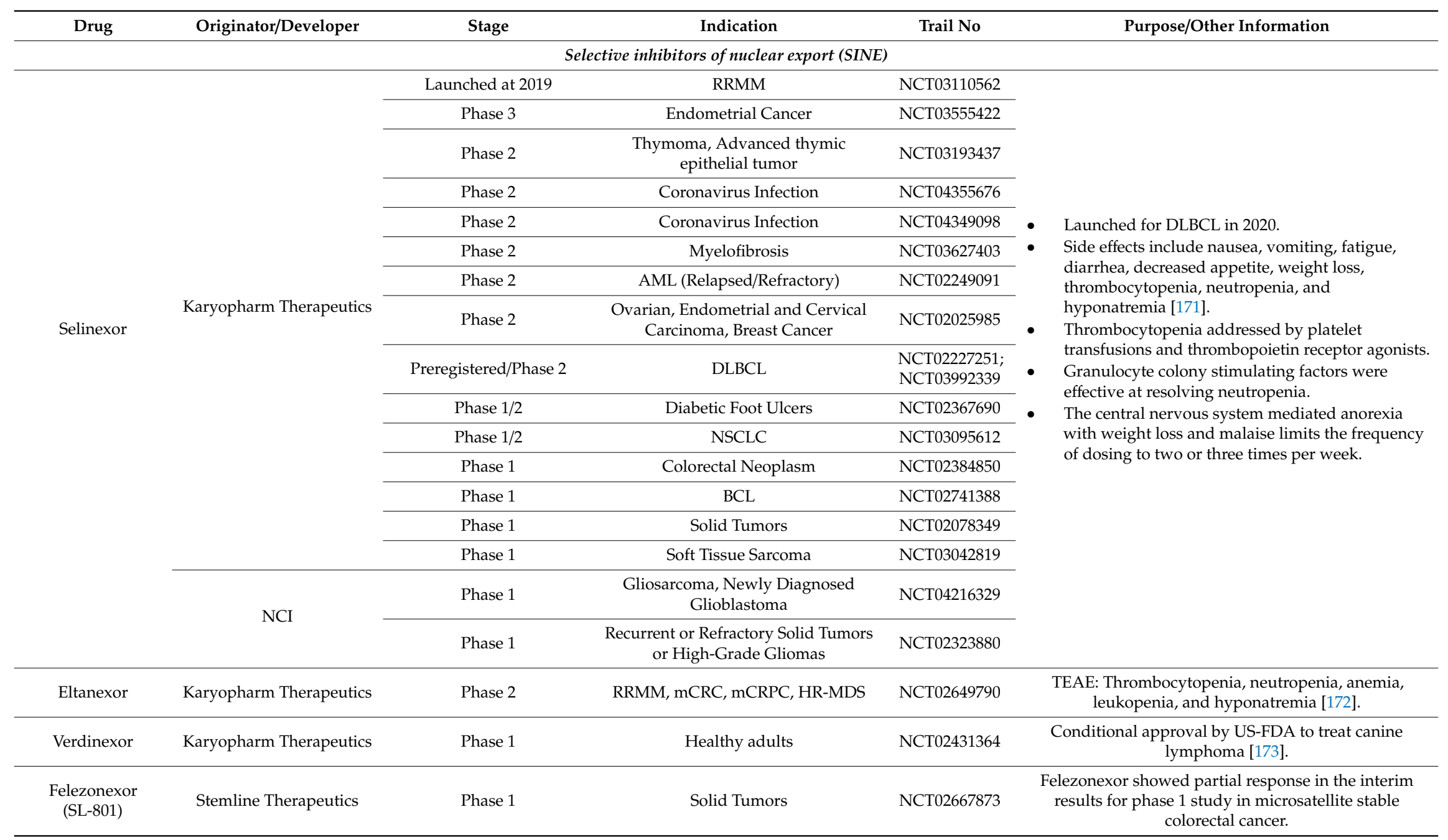


Table 5. Cont.

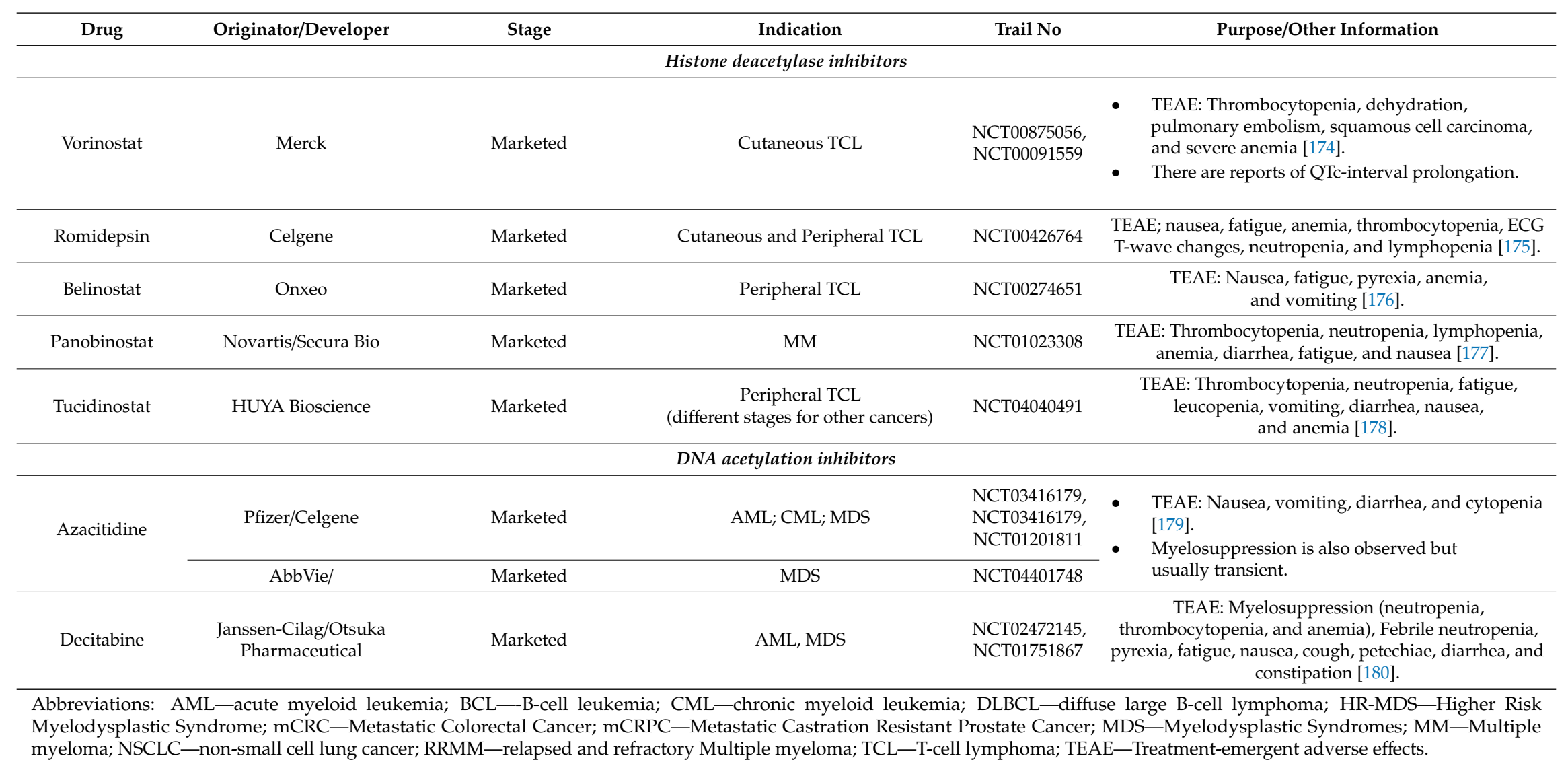




\subsection{Nuclear Import Inhibitors}

From the therapeutic view, nuclear export inhibitors are more explored in clinical settings than nuclear import inhibitors and the latter have not entered any clinical trial yet. Ivermectin, a marketed anti-protozoal drug, was later also found to be a specific importin $\alpha / \beta$ inhibitor. It was reported to show potential antiviral activity against both HIV- 1 and dengue virus via inhibiting importin $\alpha / \beta$ interaction with HIV-1 integrase and NS5 (non-structural protein 5) polymerase proteins respectively [181]. Importazole was reported to be an importin $\beta$ inhibitor in Xenopus egg extracts and cultured cells in vitro assay [182]. Cell permeable synthetic peptide (SN50) carries a functional domain to inhibit the NLS of p65/p50 and prevent the complex nuclear translocation [183]. Anti-inflammatory peptide-6 (AIP6) showed anti-inflammatory activity in both in-vitro and in-vivo experiments and mechanistically it inhibited p65/p50 translocation and DNA binding [184].

\subsection{Inhibition of $p 65$ Transactivation and DNA Binding}

The p65 has acidic TAD in the carboxyl-terminal end and it is essential for the regulation of the p65 target gene. Activated p65 TAD through phosphorylation enhances protein-protein interaction and interact with 27 various co-transcriptional regulators such as TBP, p300 and ATR etc. [185]. For the therapeutic interventions, competing p65 peptide has been used to encompass the $\mathrm{TAD}$ and to inhibit conformational changes that further prevent transactivation of p65. Synthetic peptide, GILZ (glucocorticoid-induced leucine zipper) mimetic and Smad4-binding domain peptide encompasses the TAD and inhibit the transactivation. Currently, there are no small molecule inhibitors available that target p65 TAD. Similarly decoy NF-kB nucleotides bind with p65 RHD which further inhibits the interaction of p65 with cis-elements of the target gene in the DNA. At present, no small molecule is developed to modify interaction $[186,187]$.

\subsection{Inhibition of Post-Translational Modifications}

Various transcriptional factors regulate gene expression through PMTs, where NF- $\mathrm{kB}$ is one of the important transcriptional factors regulates gene expression via PMTs. Transcriptional activities of NF-kB are regulated by many PMTs such as acetylation, ubiquitination, phosphorylation, methylation, sulfydration, nitrosylation, and sumoylation. Reversible acetylation is one of the important PMT for p65 and it is mainly regulated by HAT and HDAC enzymes. Acetylation of p65 happens predominately on lysine residue mainly by transcriptional coactivators p300/CBP and some lysine residues by PCAF $[163,186,188]$. Modulation of reversible acetylation is extensively explored for therapeutic intervention, particularly HAT and HDAC enzymes. To date, many HAT and HDAC inhibitors are approved or in ongoing clinical trials for various indications. Similarly, DNA methylation is another important PMTs regulated by DNA methyltransferases (DNMT) and inhibitors of DNMT are currently in many clinical trials for various indications. For the last two decades, a considerable number of epigenetic-targeted small molecules got FDA approval, such as Azacitidine, Decitabine, Vorinostat, Romidepsin, Belinostat, Panobinostat, and Tucidinostat for various therapeutic indications. Especially HDAC inhibitors studied extensively in drug discovery and few of them approved in the clinic [189] (Table 5).

\section{Molecules that Can or May be Repurposed as NF- $\kappa$ B Pathway Inhibitors}

In addition to the small molecules that were designed to inhibit specific targets in NF- $\mathrm{kB}$ pathways, many that were pursued for unrelated targets were later also found to inhibit NF- $\kappa B$ signaling. As discussed earlier, many molecules like Dasatinib, Olafertinib and Pacritinib were originally intended for other targets. It should be noted that in these the intended therapeutic actions may very well be an outcome of synergistic inhibition of all the targets. There are still other classes of compounds where the drugs marketed of an unrelated indication are later found to inhibit NF- $\mathrm{KB}$ pathways and may be repurposed for the same. We have already discussed DMARD like Sulfasalazine and NSAID like 
Aspirin and Salicylate reported to have IKK $\alpha$ inhibitory activity. Gabexate marketed as Anticoagulant was also found to be effective in treating patients with sepsis-associated TNF $\alpha$ mediated disseminated intravascular coagulation. It was proposed [190] to inhibit binding of AP1 and of NF-kB to their respective target inhibiting activation of mitogen-activated protein kinase (MAPK) pathways and prevent proteolytic degradation of $\mathrm{I} \kappa \mathrm{B} \alpha$.

Glucocorticoids (Prednisolone and Vamorolone) are well known for their potent anti-inflammatory activities [191] (https://www.reveragen.com/vamorolone/). Their binding to cytoplasmic nuclear hormone receptor (glucocorticoid receptor) was reported to have a transrepression activity and they are also known to repress the action of NF- $\mathrm{KB}$ gene activation. Macrolides (Erythromycin and Azithromycin) are also reported [192] for their anti-inflammatory activity as they downregulate cytokine gene expression by inhibiting transcriptional activation of NF- $\mathrm{kB}$. These molecules were originally designed and are being marketed for more than a decade as antibacterial drugs. The activity of these 14-15 member macrolides has propelled research into 12 member analogs that do not show their original antibacterial activity but retain anti-inflammatory properties [193]. Existing know-how of macrolides can assist these analogs in their discovery and development stages.

Polyphenols like curcumin, capsaicin, apigenin, oleandrin, quercetin, resveratrol, cinnamaldehyde, epigallocatechin-3-gallate, etc. are well known for their anti-inflammatory properties [194-196] and mostly act through arachidonic acid dependent and independent pathways. While the former involves COX, the latter is generally mediated through NF- $\kappa$ B. They inhibit the NF- $\kappa B$ signaling by either preventing I $\kappa \mathrm{B}$ degradation by inhibiting phosphorylation or ubiquitination of relevant kinases or inhibiting the interaction of NF- $\mathrm{kB}$ subunits with DNA.

Iguratimod, a disease modified anti-rheumatic drug (DMARD) is known to inhibit the production of immunoglobulins and cytokines and regulate T lymphocyte subsets at the synovial joints [197]. Iguratimod was also reported [198] to inhibit nuclear translocation of NF-KB p65. Mepacrine is an antiprotozoal, antirheumatic, and an intrapleural sclerosing agent. Apart from histamine $\mathrm{N}$-methyltransferase inhibitory activity, it is a DNA intercalating agent that also inhibits the NF- $\mathrm{KB}$ pathway [199]. Dimethyl fumerate (one of the active ingredient of Fumaderm) is prescribed for Psoriasis and relapsing multiple sclerosis. One of their mode of action is by interacting with glutathione that leads to the inhibition of NF- $\mathrm{kB}$ nuclear translocation and its transcriptional activity [200]. It was reported to inhibit nuclear translocation of NF-kB p50/p65 heterodimers.

\section{Conclusions and Way Forward}

NF- $\kappa B$ pathways play a critical role in almost all chronic diseases and are well-studied and mapped out. They involve multiple players that not only play key roles in signaling, but also are targetable from a drug discovery aspect. This has prompted researchers all over the world to explore thousands of molecules for modulating this pathway. As of date many of these potent drugs are in clinical trials or launched successfully (Figure 4) for diverse therapeutic intervention. Added to this many of the drugs that are currently in use with an unknown or different mechanism was later shown to modulate this pathway also. This is especially true for small molecules that often participate in multiple modes of action. Identification of established drugs showing additional NF- $\mathrm{kB}$ activity has led to the repurposing of drugs for new indications and thus further propelled research in this field. 


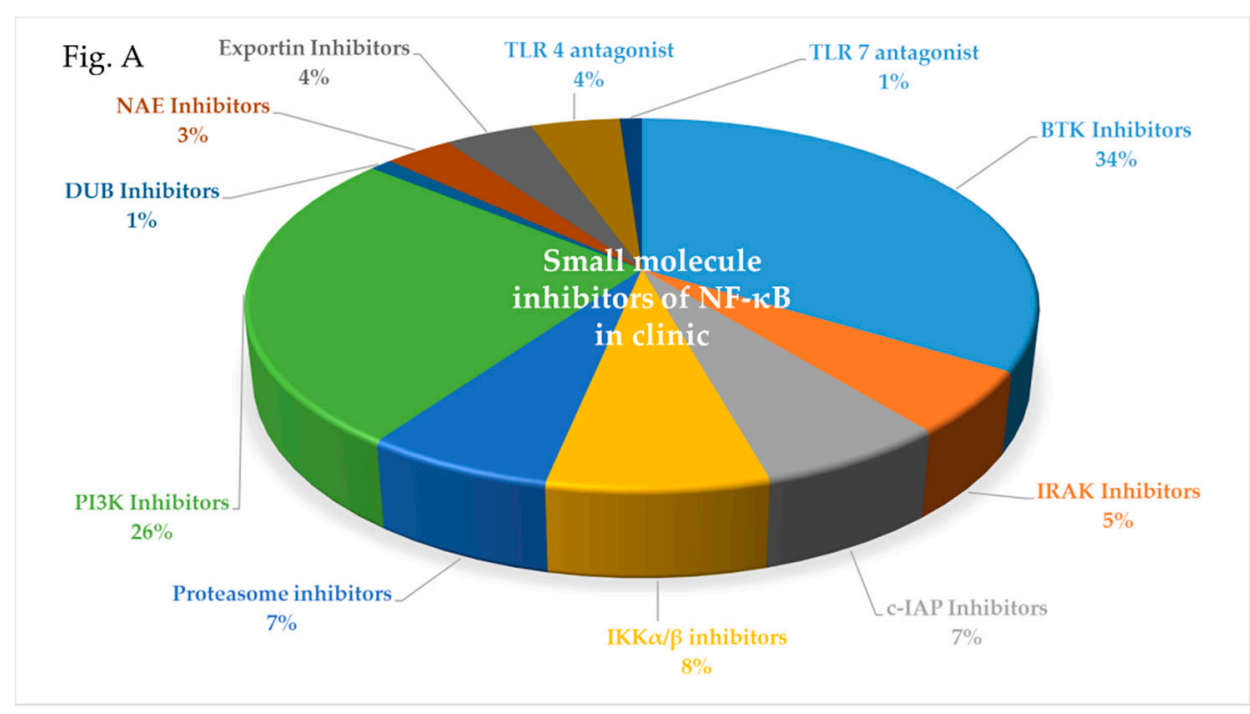

Fig. B

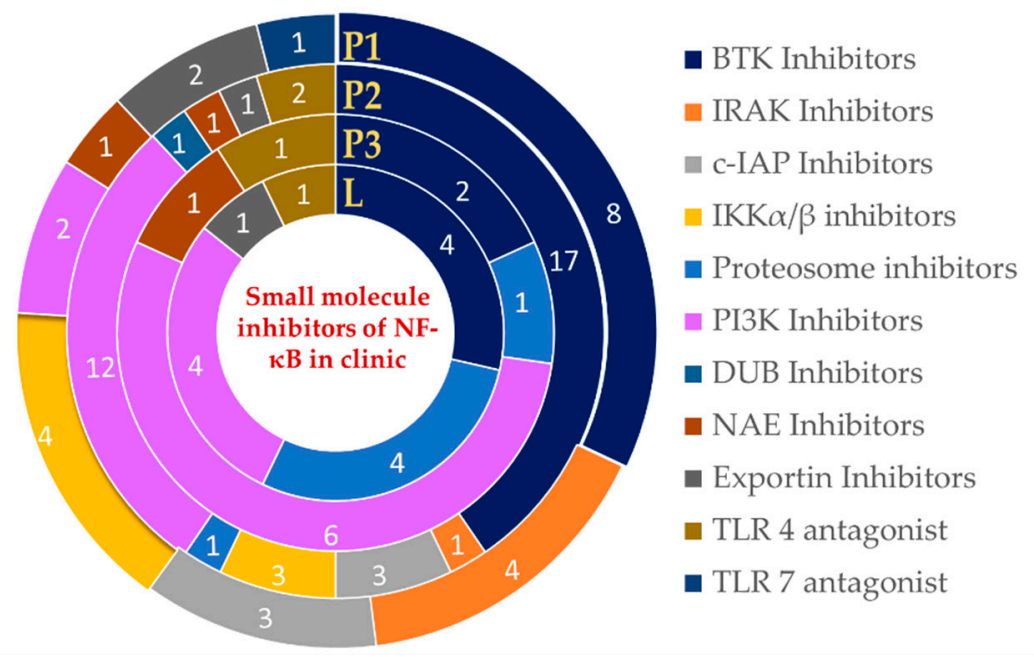

Figure 4. (A) Percentage distribution of small molecule inhibitors from various targets in NF- $\mathrm{k}$ pathways reached in the clinic for different indications. (B) Similarly, the number of small molecule inhibitors from various targets in NF-kB pathways placed in phase 1(P1), phase 2(P2), phase 3(P3), and launched $(\mathrm{L})$ in clinical trials.

Looking forward, we will definitely see more compounds that inhibit NF- $\mathrm{kB}$ pathways that not only will qualify for clinical trials but also get approved for administration in patients. As our understanding of the pathway improves, we will see more focus research in the area of designing inhibitors to their therapeutic area of applications. We anticipate that compounds, instead of getting broad coverage, will be focusing on specific indications or even subtypes. With proper patient stratifications using relevant biomarkers [201], inhibitors of BTK, IRAK, cIAP, PI3K, and even AKT and NAE will see more success in clinical trials. IKK complex inhibitors, one of the main focus of the research due to its central role in NF- $\mathrm{KB}$ pathways is challenged by the failure of IKK $\alpha / \mathrm{IKK} \beta$ inhibitors in the clinic. More selective non-ATP competitive inhibitors, use of isoform-specific readouts to differentiate the role of IKK $\alpha$ vs. IKK $\beta$ in cellular activity, and appropriate therapeutic application should lead to more clinical success. Alternatively, inhibition of IKK $\gamma$ that leads to lower ADR will be more beneficial. The clinical success of IKK $\gamma$ inhibitors and for other such peptides/pseudopeptides modulated targets, will in turn depend on strategies to overcome the proteasomal degradation and delivery to the site of action. Furthermore, targeting the disease-specific downstream effector of the unregulated NF- $\mathrm{KB}$ pathway provides a much safer alternative. Gadd45 $\beta$ (growth arrest and DNA damage 45B)/MKK7 interaction suppresses MKK7/JNK-induced apoptosis and promotes proliferation in cancerous cells. 
DTP3, a D-tripeptide inhibitor disrupts this interaction and induces apoptosis of cancerous cells [25]. Unlike upstream targets, targeting this should be less toxic to healthy cells. Imperial College London was exploring a Phase 1/2 dose-escalation study in patients with RRMM [202] but not much progress has been reported. For synthetic lethal targets like TBK1 and ATM, clinical trials in disease with specific mutations or studies with relevant combinations are being explored for success. In a few other targets, biology is still in the grey area and their role in modulating the disease, especially in the clinic is yet to be established. NIK is one such example where appropriate indication (beyond MM) or relevant combination needs to be worked out for clinical consideration. Last but definitely not the least, drugs in use that additionally showed NF- $\mathrm{KB}$ activity should be actively explored and be used as templates as novel scaffolds.

Author Contributions: Writing-review, editing and visualization, V.R. and T.V.; supervision, V.T. All authors have read and agreed to the published version of the manuscript.

Funding: This research was funded by NRF-CRP grant, grant number NRF-CRP17-2017-02.

Acknowledgments: We would like to acknowledge the valuable support provided by Michelle Shuling Ong and Dhakshayini in proof reading the manuscript and for giving suggestions to improve it further.

Conflicts of Interest: The authors declare no conflict of interest. The funders had no role in the design of the study; in the collection, analyses, or interpretation of data; in the writing of the manuscript, or in the decision to publish the results.

\section{Abbreviations}

$\begin{array}{ll}\text { ADR } & \text { Adverse drug reaction } \\ \text { AIH } & \text { Autoimmune hepatitis } \\ \text { AKT } & \text { Protein Kinase B } \\ \text { ALT } & \text { Alanine aminotransferase } \\ \text { AML } & \text { Acute myeloid leukemia } \\ \text { ATM } & \text { Ataxia telangiectasia mutated } \\ \text { BAFF } & \text { B-cell activating factor } \\ \text { BAFFR } & \text { B-cell activating factor receptor } \\ \text { BCL } & \text { B-cell leukemia } \\ \text { BCR } & \text { B-cell receptors } \\ \text { BTK } & \text { Bruton's tyrosine kinase } \\ \text { c-IAP } & \text { Cellular Inhibitor of Apoptosis Proteins } \\ \text { CLL } & \text { Chronic lymphocytic leukemia } \\ \text { CML } & \text { Chronic myeloid leukemia } \\ \text { CMML } & \text { Chronic myelomonocytic leukemia } \\ \text { COPD } & \text { Chronic obstructive pulmonary disease } \\ \text { DLBCL } & \text { Diffuse large B-cell lymphoma } \\ \text { DLT } & \text { Dose limiting toxicity } \\ \text { DMARD } & \text { Disease-modifying anti-rheumatic drug } \\ \text { DUB } & \text { Deubiquitination } \\ \text { FLT3 } & \text { FMS-like tyrosine kinase 3 } \\ \text { Fn14 } & \text { Fibroblast growth factor-inducible 14 } \\ \text { GVHD } & \text { Graft versus host disease } \\ \text { HCC } & \text { Hepatocellular carcinoma } \\ \text { IKK } & \text { IkB kinase } \\ \text { IKB } & \text { Inhibitor of kB } \\ \text { IKK } \gamma & \text { Inhibitor of nuclear factor kappa-B kinase subunit gamma } \\ \text { IL1R } & \text { Interleukin1 receptor } \\ \text { IRAK } & \text { Interleukin-1 Receptor-Associated Kinase } \\ \text { IRF } & \text { Interferon regulatory factor } \\ \text { JAK } & \text { Janus Kinase } \\ \text { JNK } & \text { c-jun N-terminal kinase } \\ \text { LT } & \text { Lymphotoxin } \\ \end{array}$


mAbs Monoclonal antibodies

MAPK Mitogen-activated protein kinase

MCL Mantle cell lymphoma

MM Multiple myeloma

MS Multiple sclerosis

MTD Maximum tolerated dose

MZL Marginal zone lymphoma

NAE NEDD8 activating enzyme

NASH Non-alcoholic steatohepatitis

NBD NEMO Binding Domain

NEMO NF- $\kappa$ B essential modulator

NES Nuclear export signal

NF-кB Nuclear factor kappa B

NHL Non-Hodgkin lymphoma

$\mathrm{NIH}$ National Institutes of Health

NIK NF- $\kappa$ B inducing kinase

NLS Nuclear localization signals

NPCs Nuclear pore complexes

NSCLC Non-small cell lung cancer

OA Osteoarthritis

ORR Overall Response Rate

PI3K Phosphatidyl Inositol-3 kinases

PK Pharmacokinetic

PDn Pharmacodynamic

RP2D Recommended phase 2 dose

RA Rheumatoid arthritis

RANK Receptor activator of NF- $\mathrm{KB}$

RANKL Receptor activator of NF- $\mathrm{KB}$ ligand

RRCLL Relapsed and refractory chronic lymphocytic leukemia

RRWM Relapsed and refractory Multiple myeloma

RA Rheumatoid arthritis

RANK Receptor activator of nuclear factor $\mathrm{k} B$

SAR Seasonal allergic rhinitis

siRNA Small interfering RNA

SLL Small lymphocytic lymphoma

SLE Systemic lupus erythematosus

SMAC Second mitochondria-derived activator of caspase

STING Stimulator of interferon genes

TAK1 Transforming growth factor beta-activated kinase 1

TBK1 IKKe and Tank binding kinase 1

TCL T-cell lymphoma

TCR T-cell receptors

TEAE Treatment-emergent adverse effects

TLR7 Toll-like receptor 7

TNF- $\alpha \quad$ Tumor necrosis factor alfa

TNFR TNF- $\alpha$ receptor

TNFRSF TNF receptor superfamily

TRAF TNF receptor-associated factor

TWEAK Tumor necrosis factor-like weak inducer of apoptosis

UPS Ubiquitin-proteasome system

WM Waldenstrom macroglobulinemia.

XIAP X-linked inhibitor of apoptosis protein 


\section{References}

1. Sen, R.; Baltimore, D. Multiple nuclear factors interact with the immunoglobulin enhancer sequences. Cell 1986, 46, 705-716. [CrossRef]

2. Ang, H.L.; Tergaonkar, V. Notch and NFkappaB signaling pathways: Do they collaborate in normal vertebrate brain development and function? Bioessays 2007, 29, 1039-1047. [CrossRef]

3. Correa, R.G.; Matsui, T.; Tergaonkar, V.; Rodriguez-Esteban, C.; Izpisua-Belmonte, J.C.; Verma, I.M. Zebrafish IkappaB kinase 1 negatively regulates NF-kappaB activity. Curr. Biol. 2005, 15, 1291-1295. [CrossRef]

4. Garbati, M.R.; Gilmore, T.D. Inhibition of NF-kB signaling as a strategy in disease therapy. In NF-kB in Health and Disease. Current Topics in Microbiology and Immunology; Springer: Berlin, Heidelberg, 2011; Volume 349, pp. 245-263.

5. Chew, C.L.; Conos, S.A.; Unal, B.; Tergaonkar, V. Noncoding RNAs: Master regulators of inflammatory signaling. Trends Mol. Med. 2018, 24, 66-84. [CrossRef] [PubMed]

6. Li, Y.; Cheng, H.S.; Chng, W.J.; Tergaonkar, V. Activation of mutant TERT promoter by RAS-ERK signaling is a key step in malignant progression of BRAF-mutant human melanomas. Proc. Natl. Acad. Sci. USA 2016, 113, 14402-14407. [CrossRef] [PubMed]

7. Ozturk, M.B.; Li, Y.; Tergaonkar, V. Current insights to regulation and role of telomerase in human diseases. Antioxidants 2017, 6, 17. [CrossRef] [PubMed]

8. Puar, Y.R.; Shanmugam, M.K.; Fan, L.; Arfuso, F.; Sethi, G.; Tergaonkar, V. Evidence for the involvement of the master transcription factor NF-kappaB in cancer initiation and progression. Biomedicines 2018, 6, 82. [CrossRef]

9. Xu, X.; Li, Y.; Bharath, S.R.; Ozturk, M.B.; Bowler, M.W.; Loo, B.Z.L.; Tergaonkar, V.; Song, H. Structural basis for reactivating the mutant TERT promoter by cooperative binding of p52 and ETS1. Nat. Commun. 2018, 9, 3183. [CrossRef]

10. Cildir, G.; Pant, H.; Lopez, A.F.; Tergaonkar, V. The transcriptional program, functional heterogeneity, and clinical targeting of mast cells. J. Exp. Med. 2017, 214, 2491-2506. [CrossRef]

11. Khattar, E.; Maung, K.Z.Y.; Chew, C.L.; Ghosh, A.; Mok, M.M.H.; Lee, P.; Zhang, J.; Chor, W.H.J.; Cildir, G.; Wang, C.Q.; et al. Rap1 regulates hematopoietic stem cell survival and affects oncogenesis and response to chemotherapy. Nat. Commun. 2019, 10, 5349. [CrossRef]

12. Herscovitch, M.; Gilmore, T.D. Inhibitors of NF-kB signaling: 785 and counting. Oncogene 2006, 25, 6887-6899.

13. Zhang, Q.; Lenardo, M.J.; Baltimore, D. 30 Years of NF-kB: A blossoming of relevance to human pathobiology. Cell 2017, 168, 37-57. [CrossRef] [PubMed]

14. Hayden, M.S.; Ghosh, S. NF- $\mathrm{BB}$, the first quarter-century: Remarkable progress and outstanding questions. Genes Dev. 2012, 26, 203-234. [CrossRef] [PubMed]

15. Sun, S.C.; Ley, S.C. New insights into NF-кB regulation and function. Trends Immunol. 2008, 29, 469-478. [PubMed]

16. Hayden, M.S.; Ghosh, S. Shared principles in NF-kB signaling. Cell 2008, 132, 344-362. [CrossRef]

17. Vallabhapurapu, S.; Karin, M. Regulation and function of NF- $\mathrm{KB}$ transcription factors in the immune system. Annu. Rev. Immunol. 2009, 27, 693-733. [CrossRef]

18. Cildir, G.; Low, K.C.; Tergaonkar, V. Noncanonical NF-kB Signaling in Health and Disease. Trends Mol. Med. 2016, 22, 414-429. [CrossRef]

19. Sun, S.C. The noncanonical NF-kB pathway. Immunol. Rev. 2012, 246, 125-140. [CrossRef]

20. Xiao, G.; Harhaj, E.W.; Sun, S.C. NF-кB-inducing kinase regulates the processing of NF-кB2 p100. Mol. Cell 2001, 7, 401-409. [CrossRef]

21. Herrington, F.D.; Carmody, R.J.; Goodyear, C.S. Modulation of NF-кB signaling as a therapeutic target in autoimmunity. J. Biomol. Screen. 2016, 21, 223-242. [CrossRef]

22. Fukuoka, M.; Yoshioka, K.; Hohjoh, H. NF- $\kappa$ B activation is an early event of changes in gene regulation for acquiring drug resistance in human adenocarcinoma PC-9 cells. PLoS ONE 2018, 13, e0201796. [CrossRef] [PubMed]

23. Wang, X.; Fang, Y.; Sun, W.; Xu, Z.; Zhang, Y.; Wei, X.; Ding, X.; Xu, Y. Endocrinotherapy resistance of prostate and breast cancer: Importance of the NF-кB pathway. Int. J. Oncol. 2020, 56, 1064-1074. [CrossRef] 
24. Nisr, R.B.; Shah, D.S.; Ganley, I.G.; Hundal, H.S. Proinflammatory NFkB signalling promotes mitochondrial dysfunction in skeletal muscle in response to cellular fuel overloading. Cell. Mol. Life Sci. 2019, 76, 4887-4904. [CrossRef] [PubMed]

25. Bennett, J.; Capece, D.; Begalli, F.; Verzella, D.; D'Andrea, D.; Tornatore, L.; Franzoso, G. NF-kB in the crosshairs: Rethinking an old riddle. Int. J. Biochem. Cell Biol. 2018, 95, 108-112. [CrossRef] [PubMed]

26. Kaltschmidt, C.; Banz-Jansen, C.; Benhidjeb, T.; Beshay, M.; Förster, C.; Greiner, J.; Hamelmann, E.; Jorch, N.; Mertzlufft, F.; Pfitzenmaier, F.; et al. A role for NF-kB in organ specific cancer and cancer stem cells. Cancers (Basel) 2019, 11, 655.

27. Catrysse, L.; van Loo, G. Inflammation and the metabolic syndrome: The tissue-specific functions of NF- $\mathrm{kB}$. Trends Cell Biol. 2017, 27, 417-429.

28. Gupta, S.C.; Sundaram, C.; Reuter, S.; Aggarwal, B.B. Inhibiting NF-kB activation by small molecules as a therapeutic strategy. Biochim. Biophys. Acta 2010, 1799, 775-787. [CrossRef]

29. Gurevich, E.V.; Gurevich, V.V. Therapeutic potential of small molecules and engineered proteins. Handb. Exp. Pharmacol. 2014, 219, 1-12.

30. Nwibo, D.D.; Levi, C.A.; Nwibo, M.I. Small molecule drugs; down but not out: A future for medical research and therapeutics. IOSR JDMS 2015, 14, 70-77.

31. Talevi, A. Multi-target pharmacology: Possibilities and limitations of the "skeleton key approach" from a medicinal chemist perspective. Front. Pharmacol. 2015, 6, 205. [CrossRef]

32. Buvailo, A. Will Biologics Surpass Small Molecules in the Pharma Race? Available online: https://www. biopharmatrend.com/post/67-will-small-molecules-sustain-pharmaceutical-race-with-biologics/ (accessed on 13 May 2020).

33. Begalli, F.; Bennett, J.; Capece, D.; Verzella, D.; D'Andrea, D.; Tornatore, L.; Franzoso, G. Unlocking the NF- $\kappa B$ Conundrum: Embracing Complexity to Achieve Specificity. Biomedicines 2017, 5, 50. [CrossRef] [PubMed]

34. Tracey, D.; Klareskog, L.; Sasso, E.H.; Salfeld, J.G.; Tak, P.P. Tumor necrosis factor antagonist mechanisms of action: A comprehensive review. Pharmacol. Ther. 2008, 117, 244-279. [CrossRef] [PubMed]

35. Ono, T.; Hayashi, M.; Sasaki, F.; Nakashima, T. RANKL biology: Bone metabolism, the immune system, and beyond. Inflamm. Regen. 2020, 40, 2. [CrossRef] [PubMed]

36. van der Weyden, C.A.; Pileri, S.A.; Feldman, A.L.; Whisstock, J.; Prince, H.M. Understanding CD30 biology and therapeutic targeting: A historical perspective providing insight into future directions. Blood Cancer J. 2017, 7, e603. [CrossRef] [PubMed]

37. O'Connell, J.; Porter, J.; Kroeplien, B.; Norman, T.; Rapecki, S.; Davis, R.; McMillan, D.; Arakaki, T.; Burgin, A.; III, D.F.; et al. Small molecules that inhibit TNF signalling by stabilising an asymmetric form of the trimer. Nat. Commun. 2019, 10, 1-12.

38. Anwar, M.A.; Shah, M.; Kim, J.; Choi, S. Recent clinical trends in Toll-like receptor. Med. Res. Rev. 2019, 39, 1053-1090. [CrossRef]

39. Idera Announces FDA Prphan Dryg Designation for IMO-8400 for the Treatment of Diffuse Large B-Cell Lymphoma. Available online: http://ir.iderapharma.com/news-releases/news-release-details/ideraannounces-fda-orphan-drug-designation-imo-8400-treatment (accessed on 5 May 2020).

40. FORM 10-K, Annual Report: Fiscal Year Ended. 31 December $2016 . \quad$ Available online: https://www.sec.gov/Archives/edgar/data/861838/000155837017001845/idra-20161231x10k.htm\# Item16Form10KSummary_498298 (accessed on 5 May 2020).

41. Pharmaceuticals, T. Clinical Trial Arena. Available online: https:/www.clinicaltrialsarena.com/comment/ taiwanjs-jkb-121-falls-victim-unexpected-placebo-response-nash-patients/ (accessed on 12 May 2020).

42. JKB-122. Clinical Trial Arena. Available online: https://www.clinicaltrialsarena.com/news/taiwanj-reportspositive-data/ (accessed on 22 May 2020).

43. Novack, D.V.; Yin, L.; Hagen-Stapleton, A.; Schreiber, R.D.; Goeddel, D.V.; Ross, F.P.; Teitelbaum, S.L. The IkappaB function of NF-kappaB2 p100 controls stimulated osteoclastogenesis. J. Exp. Med. 2003, 198, 771-781. [CrossRef]

44. FDA Approves Amgens XGEVA Denosumab for the Treatment of Hypercalcemia of Malignancy Refractory to Bisposphonate Therapy. Available online: https://www.amgen.com/media/news-releases/2014/12/fdaapproves-amgens-xgeva-denosumab-for-the-treatment-of-hypercalcemia-of-malignancy-refractory-tobisphosphonate-therapy/ (accessed on 13 May 2020). 
45. FDA Approves XGEVA Denosumab for the Prevention of Skeletal Relevated Events in Patients with Multiple Myeloma. Available online: https://www.amgen.com/media/news-releases/2018/01/fda-approves-xgevadenosumab-for-the-prevention-of-skeletalrelated-events-in-patients-with-multiple-myeloma/ (accessed on 13 May 2020).

46. FDA Approves PROLIA Denosumab for Glucocorticoid Induced Osteoporosis. Available online: https://www.amgen.com/media/news-releases/2018/05/fda-approves-prolia-denosumab-forglucocorticoidinduced-osteoporosis/ (accessed on 13 May 2020).

47. Tyan, A.; Patel, S.P.; Block, S.; Hughes, T.; McCowen, K.C. Rebound vertebral fractures in a patient with lung cancer after oncology-dose Denosumab discontinuation: A cautionary tale. MCP IQ O 2019, 3, 235-237. [CrossRef]

48. Jiang, M.; Peng, L.; Yang, K.; Wang, T.; Yan, X.; Jiang, T.; Xu, J.; Qi, J.; Zhou, H.; Qian, N.; et al. Development of small-molecules targeting Receptor Activator of Nuclear Factor- $\kappa B$ Ligand (RANKL) 一 Receptor Activator of Nuclear Factor- $\mathrm{B}$ (RANK) protein-protein interaction by structure-based virtual screening and hit optimization. J. Med. Chem. 2019, 62, 5370-5381. [CrossRef]

49. VBL Therapeutics Reports Topline Results From Phase 2 Studies of VB-201 in Psoriasis and Ulcerative Colitis. Available online: https://www.vblrx.com/vbl-therapeutics-reports-topline-results-from-phase-2-studies-ofvb-201-in-psoriasis-and-ulcerative-colitis/ (accessed on 1 July 2020).

50. Kaptein, A.; Bruin, G.D.; Hoek, M.E.-V.; Kar, B.V.D.; Jong, A.D.; Gulrajani, M.; Demont, D.; Covey, T.; Mittag, D.; Barf, T. Potency and selectivity of BTK inhibitors in clinical development for B-cell malignancies. Blood 2018, 132, 1871.

51. Owen, C.; Berinstein, N.L.; Christofides, A.; Sehn, L.H. Review of Bruton tyrosine kinase inhibitors for the treatment of relapsed or refractory mantle cell lymphoma. Curr. Oncol. 2019, 26, e233-e240. [CrossRef] [PubMed]

52. Astor, L. FDA Approves Acalabrutinib for CLL/SLL. Available online: https://www.targetedonc.com/view/ fda-approves-acalabrutinib-for-cllsll (accessed on 5 May 2020).

53. FDA Grants Accelerated Approval to Zanubrutinib for Mantle Cell Lymphoma. Available online: https://www.fda.gov/drugs/resources-information-approved-drugs/fda-grants-accelerated-approvalzanubrutinib-mantle-cell-lymphoma (accessed on 5 May 2020).

54. Smith, J. Orelabrutinib could be 'Preferred' BTK Inhibitor for MCL. Available online: https://www.mdedge. com/hematology-oncology/article/214174/mantle-cell-lymphoma/orelabrutinib-could-be-preferred-btk (accessed on 5 May 2020).

55. Wankhade, S. Ono Pharma Seeks Japanese Approval for Tirabrutinib. Available online: https://www. biospectrumasia.com/news/50/14985/ono-pharma-seeks-japanese-approval-for-tirabrutinib-.html (accessed on 5 May 2020).

56. Kutsch, N.; Pallasch, C.; Decker, T.; Hebart, H.; Chow, K.U.; Graeven, U.; Kisro, J.; Kroeber, A.; Tausch, E.; Wendtner, C.M.; et al. A prospective, open-label, multicenter, phase 2 trial to evaluate the safety and efficacy of the combination of Tirabrutinib (ONO/GS-4059) and Idelalisib with and without Obinutuzumab in patients with relapsed/refractory chronic lymphocytic leukemia (CLL). Blood 2019, 134, 3047.

57. Rule, S.A.; Cartron, G.; Fegan, C.; Morschhauser, F.; Han, L.; Mitra, S.; Salles, G.; Dyer, M.J.S. Long-term follow-up of patients with mantle cell lymphoma (MCL) treated with the selective Bruton's tyrosine kinase inhibitor tirabrutinib (GS/ONO-4059). Leukemia Vol. 2020, 34, 1458-1461. [CrossRef]

58. Sanofi Brain-Penetrant BTK Inhibitor Meets Primary Endpoint of Phase 2 Trial in Relapsing Multiple Sclerosis. Available online: https://www.sanofi.com/en/media-room/press-releases/2020/2020-02-06-07-00-00 (accessed on 6 May 2020).

59. Chee, C.E.; Krishnamurthi, S.; Nock, C.J.; Meropol, N.J.; Gibbons, J.; Fu, P.; Bokar, J.; Teston, L.; O’Brien, T.; Gudena, V.; et al. Phase II study of Dasatinib (BMS-354825) in patients with metastatic adenocarcinoma of the pancreas. Oncologist 2013, 18, 1091-1092. [CrossRef]

60. Tsou, P.-S.; Haak, A.J.; Khanna, D.; Neubig, R.R. Cellular Mechanisms of Tissue Fibrosis. 8. Current and future drug targets in fibrosis: Focus on Rho GTPase-regulated gene transcription. Am. J. Physiol. Cell Physiol. 2014, 307, C2-C13.

61. Acalabrutinib. In LiverTox: Clinical and Research Information on Drug-Induced Liver Injury; Bethesda (MD): Rockville, MD, USA, 2012. 
62. Levy, I.; Polliack, A.; Tadmor, T. Five Ibrutinib-associated side effects that all clinicians should be aware of. Acta Haematol. 2019, 141, 254-255. [CrossRef]

63. Conchon, M.; Freitas, C.M.; Rego, M.A.; Braga Junior, J.W. Dasatinib - clinical trials and management of adverse events in imatinib resistant/intolerant chronic myeloid leukemia. Rev. Bras. Hematol. Hemoter. 2011, 33, 131-139. [CrossRef]

64. Nagane, M.; Narita, Y.; Mishima, K.; Terui, Y.; Arakawa, Y.; Yonezawa, H.; Asai, K.; Fukuhara, N.; Sugiyama, K.; Shinojima, N.; et al. Phase 1/2 study of Tirabrutinib (ONO/GS-4059), a next-generation Bruton's Tyrosine Kinase (BTK) inhibitor, monotherapy in patients with relapsed/refractory Primary Central Nervous System Lymphoma (PCNSL). Blood 2019, 134, 1586. [CrossRef]

65. New late-breaking data at EAN indicate Evobrutinib is the first BTK inhibitor to report efficacy and safety in MS over 108 Weeks. Available online: https://www.prnewswire.com/news-releases/new-late-breakingdata-at-ean-indicate-evobrutinib-is-the-first-btk-inhibitor-to-report-efficacy-and-safety-in-ms-over-108weeks-301064619.html (accessed on 2 July 2020).

66. Song, Y.; Song, Y.; Liu, L.; Zhang, M.; Li, Z.; Ji, C.; Xu, W.; Liu, T.; Xu, B.; Wang, X.; et al. Safety and efficacy of Orelabrutinib monotherapy in Chinese patients with relapsed or refractory mantle celllLymphoma: A multicenter, open-label, phase II study. Blood 2019, 134, 755. [CrossRef]

67. Sanofi's BTK inhibitor SAR442168 significantly reduced disease activity in Phase $2 \mathrm{~b}$ trial in relapsing multiple sclerosis. Available online: https://www.trialsitenews.com/sanofis-btk-inhibitor-sar442168-significantlyreduced-disease-activity-in-phase-2b-trial-in-relapsing-multiple-sclerosis/ (accessed on 2 July 2020).

68. Catlett, I.M.; Nowak, M.; Kundu, S.; Zheng, N.; Liu, A.; He, B.; Girgis, I.G.; Grasela, D.M. Safety, pharmacokinetics and pharmacodynamics of branebrutinib (BMS-986195), a covalent, irreversible inhibitor of Bruton's tyrosine kinase: Randomised phase I, placebo-controlled trial in healthy participants. Br. J. Clin. Pharmacol. 2020. [CrossRef] [PubMed]

69. Kumagai, Y.; Tanaka, Y.; Murata, M.; Takeuchi, T. FRI0156 a phase 1, single and multiple ascending dose study of TAS5315-A novel highly selective inhibitor of Bruton's tyrosine kinase-in healthy male volunteers. Ann. Rheum. Dis. 2019, 78, 750. [CrossRef]

70. Lee, S.K.; Xing, J.; Catlett, I.M.; Adamczyk, R.; Griffies, A.; Liu, A.; Murthy, B.; Nowak, M. Safety, pharmacokinetics, and pharmacodynamics of BMS-986142, a novel reversible BTK inhibitor, in healthy participants. Eur. J. Clin. Pharmacol. 2017, 73, 689-698. [CrossRef] [PubMed]

71. Cohen, S.B. Efficacy and safety of Fenebrutinib, a BTK inhibitor, compared to placebo in rheumatoid arthritis patients with active disease despite TNF inhibitor treatment: Randomized, double blind, phase 2 study. In Proceedings of the American College of Rheumatology, Atlanta, GA, USA, 10 November 2019.

72. Elvidge, S. $\$ 690 \mathrm{M}$ deal in peril after Lilly ends mid-stage studies. Available online: https://www. biopharmadive.com/news/690m-deal-in-peril-after-lilly-ends-mid-stage-studies/517372/ (accessed on 2 July 2020).

73. Jurczak, W.R.; Townsend, W.; Tucker, D.; Sarholz, B.; Scheele, J.; Gribben, J.; Zinzani, P.L. PDPhase I/II, first in human trial with M7583, a Bruton's tyrosine kinase inhibitor (BTKi), in patients with B cell malignancies. In Proceedings of the European Society for Medical Oncology (ESMO) congress, Munich, Germany, 19-23 October 2018; pp. viii359-viii371.

74. ArQule announces final phase 1 clinical data for its reversible BTK inhibitor, ARQ 531, at the American Society of Hematology. Available online: https://www.bloomberg.com/press-releases/2019-12-09/arquleannounces-final-phase-1-clinical-data-for-its-reversible-btk-inhibitor-arq-531-at-the-american-society-ofhematology (accessed on 2 July 2020).

75. Danto, S.I.; Shojaee, N.; Singh, R.S.P.; Li, C.; Gilbert, S.A.; Manukyan, Z.; Kilty, I. Safety, tolerability, pharmacokinetics, and pharmacodynamics of PF-06650833, a selective interleukin-1 receptor-associated kinase 4 (IRAK4) inhibitor, in single and multiple ascending dose randomized phase 1 studies in healthy subjects. Arthritis Res. Ther. 2019, 21, 269-285. [PubMed]

76. Younes, A.; Nowakowski, G.; Rosenthal, A.C.; Leslie, L.A.; Tun, H.W.; Lunning, M.A.; Isufi, I.; Martell, R.; Patel, K. Phase 1 dose-finding study investigating CA-4948, an IRAK4 kinase inhibitor, in patients with R/R NHL: Report of initial efficacy and updated safety information. Blood 2019, 134, 5327. [CrossRef] 
77. Rigel Initiates Phase 1 Clinical Trial of R835, an IRAK1/4 Inhibitor for Autoimmune and Inflammatory Diseases. Available online: https://www.prnewswire.com/news-releases/rigel-initiates-phase-1-clinical-trialof-r835-an-irak14-inhibitor-for-autoimmune-and-inflammatory-diseases-300672042.html (accessed on 1 July 2020).

78. Medivir, A.B. Futility analysis performed of the phase II combination study with Birinapant and Keytrudaßin colorectal cancer patients. Available online: https://www.prnewswire.com/news-releases/futility-analysisperformed-of-the-phase-ii-combination-study-with-birinapant-and-keytruda-in-colorectal-cancerpatients-300975351.html (accessed on 6 May 2020).

79. Rasco, D.W.; Li, Y.; Tang, Y.; Men, L.; Wang, H.; Ji, J.; Liang, Z.; Sun, J.; Amaya, A.; Huang, Y.; et al. A phase I study of a novel IAP inhibitor APG-1387 as a monotherapy or in combination with pembrolizumab in treatments of patients with advanced solid tumors. J. Clin. Oncol. 2019, 37, 3125. [CrossRef]

80. Pemmaraju, N.; Carter, B.Z.; Kantarjian, H.M.; Cortes, J.E.; Bose, P.; Kadia, T.M.; Garcia-Manero, G.; Bueso-Ramos, C.E.; DiNardo, C.D.; Bledsoe, S.; et al. Final results of phase 2 clinical trial of LCL161, a novel oral SMAC mimetic/IAP antagonist, for patients with intermediate to high risk myelofibrosis. Blood 2019, 134, 555. [CrossRef]

81. Mita, M.M.; LoRusso, P.M.; Papadopoulos, K.P.; Gordon, M.S.; Mita, A.C.; Ferraldeschi, R.; Keer, H.; Oganesian, A.; Su, X.Y.; Jueliger, S.; et al. A phase I study of ASTX660, an antagonist of inhibitors of apoptosis proteins, in adults with advanced cancers or lymphoma. Clin. Cancer Res. 2020, 26, 2819-2826. [CrossRef] [PubMed]

82. Tucker, N. FDA grants Breakthrough Therapy Designation to Debio 1143 in front-line head and neck cancer. Available online: https://www.targetedonc.com/view/fda-grants-breakthrough-therapy-designationto-debio-1143-in-frontline-head-and-neck-cancer (accessed on 2 July 2020).

83. Tolcher, A.W.; Bendell, J.C.; Papadopoulos, K.P.; Burris, H.A.; Patnaik, A.; Fairbrother, W.J.; Wong, H.; Budha, N.; Darbonne, W.C.; Peale, F.; et al. A Phase I Dose-Escalation Study Evaluating the Safety Tolerability and Pharmacokinetics of CUDC-427, a Potent, Oral, Monovalent IAP Antagonist, in Patients with Refractory Solid Tumors. Clin. Cancer Res. 2016, 22, 4567-4573. [CrossRef] [PubMed]

84. Rhyasen, G.W.; Starczynowski, D.T. IRAK signalling in cancer. Br. J. Cancer 2015, 112, 232-237. [CrossRef]

85. Wang, Z.; Wesche, H.; Stevens, T.; Walker, N.; Yeh, W.C. IRAK-4 inhibitors for inflammation. Curr. Top. Med. Chem. 2009, 9, 724-737. [CrossRef] [PubMed]

86. Singer, J.W.; Fleischman, A.; Al-Fayoumi, S.; Mascarenhas, O.J.; Yu, Q.; Agarwal, A. Inhibition of interleukin-1 receptor-associated kinase 1 (IRAK1) as a therapeutic strategy. Oncotarget 2018, 9, 33416-33439. [CrossRef] [PubMed]

87. Press Release on CU-4948 Phase 1 Study. Available online: http://investors.curis.com/2019-12-06Curis-Provides-First-Ever-Demonstration-that-Targeting-IRAK4-in-Patients-with-Relapsed-RefractoryNon-Hodgkins-Lymphoma-Results-in-Anti-Cancer-Activity-in-Ongoing-Phase-1-Study (accessed on 5 May 2020).

88. Manning, B.D.; Tok, A. AKT/PKB signaling: Navigating the network. Cell 2017, 169, 381-405. [CrossRef] [PubMed]

89. Ozes, O.N.; Mayo, L.D.; Gustin, J.A.; Pfeffer, S.R.; Pfeffer, L.M.; Donner, D.B. NF-kappaB activation by tumour necrosis factor requires the Akt serine-threonine kinase. Nature 1999, 401, 82-85. [CrossRef] [PubMed]

90. Reddy, S.A.; Huang, J.H.; Liao, W.S. Phosphatidylinositol 3-kinase in interleukin 1 signaling. Physical interaction with the interleukin 1 receptor and requirement in NFkappaB and AP-1 activation. J. Biol. Chem. 1997, 272, 29167-29173. [CrossRef] [PubMed]

91. Fruman, D.A.; Rommel, C. PI3K and cancer: Lessons, challenges and opportunities. Nat. Rev. Drug Discov. 2014, 13, 140-156. [CrossRef] [PubMed]

92. Ghoneum, A.; Said, N. PI3K-AKT-mTOR and NFkappaB pathways in ovarian cancer: Implications for targeted therapeutics. Cancers 2019, 11, 949. [CrossRef]

93. Pacold, M.E.; Suire, S.; Perisic, O.; Lara-Gonzalez, S.; Davis, C.T.; Walker, E.H.; Hawkins, P.T.; Stephens, L.; Eccleston, J.F.; Williams, R.L. Crystal structure and functional analysis of Ras binding to its effector phosphoinositide 3-kinase gamma. Cell 2000, 103, 931-943. [CrossRef]

94. Guo, H.; German, P.; Bai, S.; Barnes, S.; Guo, W.; Qi, X.; Lou, H.; Liang, J.; Jonasch, E.; Mills, G.B.; et al. The PI3K/AKT pathway and renal cell carcinoma. J. Genet. Genomics 2015, 42, 343-353. [CrossRef] 
95. Yang, J.; Nie, J.; Ma, X.; Wei, Y.; Peng, Y.; Wei, X. Targeting PI3K in cancer: Mechanisms and advances in clinical trials. Mol. Cancer 2019, 18, 26. [CrossRef]

96. Manning, B.D.; Cantley, L.C. AKT/PKB signaling: Navigating downstream. Cell 2007, 129, 1261-1274. [CrossRef] [PubMed]

97. Guo, K.; Tang, W.; Zhuo, H.; Zhao, P.G. Recent Advance of Akt Inhibitors in Clinical Trials. Chemistry Select 2019, 4, 9040-9044. [CrossRef]

98. Mayer, I.A.; Arteaga, C.L. The PI3K/AKT pathway as a target for cancer treatment. Annu. Rev. Med. 2016, 67, 11-28. [CrossRef] [PubMed]

99. Michie, J.; Kearney, C.J.; Hawkins, E.D.; Silke, J.; Oliaro, J. The immuno-modulatory effects of inhibitor of apoptosis protein antagonists in cancer immunotherapy. Cells 2020, 9, 207. [CrossRef] [PubMed]

100. Zhang, J.; Webster, J.D.; Dugger, D.L.; Goncharov, T.; Roose-Girma, M.; Hung, J.; Kwon, Y.C.; Vucic, D.; Newton, K.; Dixit, V.M. Ubiquitin ligases cIAP1 and cIAP2 limit cell death to prevent inflammation. Cell Rep. 2019, 27, 2679.e2673-2689.e2673. [CrossRef] [PubMed]

101. Mahoney, D.J.; Cheung, H.H.; Mrad, R.L.; Plenchette, S.; Simard, C.; Enwere, E.; Arora, V.; Mak, T.W.; Lacasse, E.C.; Waring, J.; et al. Both cIAP1 and cIAP2 regulate TNFalpha-mediated NF-kappaB activation. Proc. Natl. Acad. Sci. USA 2008, 105, 11778-11783. [CrossRef]

102. Ea, C.K.; Deng, L.; Xia, Z.P.; Pineda, G.; Chen, Z.J. Activation of IKK by TNFalpha requires site-specific ubiquitination of RIP1 and polyubiquitin binding by NEMO. Mol. Cell 2006, 22, 245-257. [CrossRef]

103. Guicciardi, M.E.; Werneburg, N.W.; Bronk, S.F.; Franke, A.; Yagita,H.; Thomas, G.; Gores, G.J. Cellular inhibitor of apoptosis (cIAP)-mediated ubiquitination of phosphofurin acidic cluster sorting protein 2 (PACS-2) negatively regulates tumor necrosis factor-related apoptosis-inducing ligand (TRAIL) cytotoxicity. PLoS ONE 2014, 9, e92124. [CrossRef]

104. Sun, H.; Lu, J.; Liu, L.; Yang, C.Y.; Wang, S. Potent and selective small-molecule inhibitors of cIAP1/2 proteins reveal that the binding of Smac mimetics to XIAP BIR3 is not required for their effective induction of cell death in tumor cells. ACS Chem. Biol. 2014, 9, 994-1002. [CrossRef]

105. Clinical Pipeline: ASTX660. Available online: https:/astx.com/research-development/clinical-pipeline/ astx660-dual-iap-antagonist-solid-tumors-lymphomas/ (accessed on 6 May 2020).

106. EMA grants Orphan Drug Designation to Debiopharm International SA'sIAP inhibitor Debio 1143 in the Treatment of Ovarian Cancer. Available online: https://www.debiopharm.com/drug-development/pressreleases/ema-grants-orphan-drug-designation-to-debiopharm-international-sas-iap-inhibitor-debio-1143in-the-treatment-of-ovarian-cancer/ (accessed on 6 May 2020).

107. Ascentage Pharma Announces Approval for the Phase Ib/II Clinical Trial of APG-1387 in Combination with Chemotherapy for the Treatment of Advanced Pancreatic Cancer in China. Available online: https://en.prnasia.com/releases/global/ascentage-pharma-announces-approval-for-the-phase-ib-ii-clinicaltrial-of-apg-1387-in-combination-with-chemotherapy-for-the-treatment-of-advanced-pancreatic-cancerin-china-273315.shtml (accessed on 6 May 2020).

108. Terry, M. TetraLogic Pharmaceuticals's New IPO Takes A Hit As Company Halts Hepatitis B Trial. Available online: https:/www.biospace.com/article/tetralogic-pharmaceuticals-s-new-ipo-takes-a-hit-ascompany-halts-hepatitis-b-trial-/ (accessed on 6 May 2020).

109. Prescott, J.A.; Cook, S.J. Targeting IKK $\beta$ in cancer: Challenges and opportunities for the therapeutic utilisation of IKK $\beta$ inhibitors. Cell 2018, 7, 115. [CrossRef]

110. Xu, M.; Skaug, B.; Zeng, W.; Chen, Z.J. A ubiquitin replacement strategy in human cells reveals distinct mechanisms of IKK activation by TNFalpha and IL-1beta. Mol. Cell 2009, 36, 302-314. [CrossRef] [PubMed]

111. Wang, C.; Deng, L.; Hong, M.; Akkaraju, G.R.; Inoue, J.; Chen, Z.J. TAK1 is a ubiquitin-dependent kinase of MKK and IKK. Nature 2001, 412, 346-351. [CrossRef] [PubMed]

112. Perkins, N.D.; Gilmore, T.D. Good cop, bad cop: The different faces of NF-kappaB. Cell Death Diff. 2006, 13, 759-772. [CrossRef] [PubMed]

113. Weber, C.K.; Liptay, S.; Wirth, T.; Adler, G.; Schmid, R.M. Suppression of NF-kB activity by sulfasalazine is mediated by direct inhibition of IKB kinases $\alpha$ and $\beta$. Gastroenterology 2000, 119, 1209-1218. [CrossRef] [PubMed]

114. Yin, M.J.; Yamamoto, Y.; Gaynor, R.B. The anti-inflammatory agents aspirin and salicylate inhibit the activity of I(kappa)B kinase-beta. Nature 1998, 396, 77-80. 
115. Goldfine, A.B.; Silver, R.; Aldhahi, W.; Cai, D.; Tatro, E.; Lee, J.; Shoelson, S.E. Use of Salsalate to Target Inflammation in the Treatment of Insulin Resistance and Type 2 Diabetes. Clin. Transl. Sci. 2008, 1, 36-43. [CrossRef]

116. Sepulveda, P.; Jobin, C.; Baldwin, A.S.; Li, P.D.F.; Karrasch, T.; Uno, J.K.; Sepulveda, A.R.; Jobin, C.; Baldwin, A.S.; Robbins, P.D.; et al. Amelioration of chronic murine colitis by peptide-mediated transduction of the IkB kinase inhibitor NEMO binding domain peptide. J. Immunol. 2007, 179, 7852-7859.

117. Rhodes, C.A.; Dougherty, P.G.; Cooper, J.K.; Qian, Z.; Lindert, S.; Wang, Q.-E.; Pei, D. Cell-permeable bicyclic peptidyl inhibitors against NEMO-IкB kinase interaction directly from a combinatorial library. J. Am. Chem. Soc. 2018, 140, 12102-12110. [CrossRef]

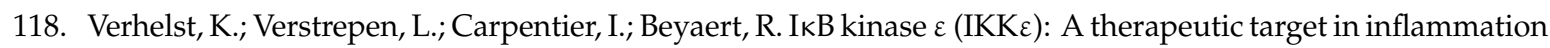
and cancer. Biochem. Pharmacol. 2013, 85, 873-880. [CrossRef]

119. Hasana, M.; Yan, N. Therapeutic potential of targeting TBK1 in autoimmune diseases and interferonopathies. Pharmacol. Res. 2016, 111, 336-342. [CrossRef]

120. Hovstadius, P.; Larsson, R.; Jonsson, E.; Skov, T.; Kissmeyer, A.M.; Krasilnikoff, K.; Bergh, J.; Karlsson, M.O.; Lonnebo, A.; Ahlgren, J. A Phase I study of CHS 828 in patients with solid tumor malignancy. Clin. Cancer Res. 2002, 8, 2843-2850. [PubMed]

121. Grothe, K.; Flechsenhar, K.; Paehler, T.; Ritzeler, O.; Beninga, J.; Saas, J.; Herrmann, M.; Rudolphi, K. IkappaB kinase inhibition as a potential treatment of osteoarthritis-Results of a clinical proof-of-concept study. Osteoarthr. Cartilage 2017, 25, 46-52. [CrossRef] [PubMed]

122. TRACON Pharmaceuticals reports fourth quarter and year-end 2018 financial results and provides corporate update. Available online: https://raconpharma.gcs-web.com/news-releases/news-release-details/traconpharmaceuticals-reports-fourth-quarter-and-year-end-2018 (accessed on 6 May 2020).

123. Stansfield, I.; Querolle, O.A.G.; Poncelet, V.S.; Gross, G.M.; Jacoby, E.; Meerpoel, L.; Kulagowski, J.J.; Macleod, C.; Mann, S.E.; Green, S.R.; et al. New Substituted Cyanoindoline Derivatives as MAP3K14 Kinase Inhibitors for the Treatment of Cancer and Autoimmune Disorders. ACS Med. Chem. Lett. 2017, 8, 908-910.

124. Pohl, C.; Dikic, I. Cellular quality control by the ubiquitin-proteasome system and autophagy. Science 2019, 366, 818-822. [CrossRef] [PubMed]

125. Thibaudeau, T.A.; Smith, D.M. A Practical Review of Proteasome Pharmacology. Pharmacol. Rev. 2019, 71, 170-197. [CrossRef]

126. Clague, M.J.; Heride, C.; Urbe, S. The demographics of the ubiquitin system. Trends Cell Biol. 2015, 25, 417-426. [CrossRef]

127. Myung, J.; Kim, K.B.; Crews, C.M. The ubiquitin-proteasome pathway and proteasome inhibitors. Med. Res. Rev. 2001, 21, 245-273. [CrossRef]

128. Ohtake, F.; Tsuchiya, H. The emerging complexity of ubiquitin architecture. J. Biochem. 2017, 161, 125-133. [CrossRef]

129. Meyer, H.J.; Rape, M. Enhanced protein degradation by branched ubiquitin chains. Cell 2014, 157, $910-921$. [CrossRef]

130. Ohtake, F.; Saeki, Y.; Ishido, S.; Kanno, J.; Tanaka, K. The K48-K63 branched ubiquitin chain regulates NF-kappaB signaling. Mol. Cell 2016, 64, 251-266. [CrossRef]

131. Sherman, D.J.; Li, J. Proteasome inhibitors: Harnessing proteostasis to combat disease. Molecules 2020, $25,671$. [CrossRef]

132. Velcade (Bortezomib). Available online: https://myelomaresearchnews.com/velcade-bortezomib/ (accessed on 8 May 2020).

133. Huang, Z.; Wu, Y.; Zhou, X.; Xu, J.; Zhu, W.; Shu, Y.; Liu, P. Efficacy of therapy with bortezomib in solid tumors: A review based on 32 clinical trials. Future Oncol. Lond. Engl. 2014, 10, 1795-1807. [CrossRef]

134. Gupta, N.; Hanley, M.J.; Xia, C.; Labotka, R.; Harvey, R.D.; Venkatakrishnan, K. Clinical Pharmacology of Ixazomib: The First Oral Proteasome Inhibitor. Clin. Pharmacokinet. 2019, 58, 431-449. [CrossRef] [PubMed]

135. Ninlaro (ixazomib). Available online: https://www.myeloma.org/treatment/current-fda-approvedmedications/ninlaro-ixazomib (accessed on 8 May 2020).

136. Takeda Provides Update on TOURMALINE-AL1 Phase 3 Trial in AL Amyloidosis. Available online: https://www.takeda.com/newsroom/newsreleases/2019/takeda-provides-update-on-tourmalineal1-phase-3-trial/ (accessed on 8 May 2020). 
137. Perel, G.; Bliss, J.; Thomas, C.M. Carfilzomib (Kyprolis): A novel proteasome inhibitor for relapsed and/or refractory multiple myeloma. P T 2016, 41, 303-307. [PubMed]

138. Waxman, A.J.; Clasen, S.; Hwang, W.T.; Garfall, A.; Vogl, D.T.; Carver, J.; O'Quinn, R.; Cohen, A.D.; Stadtmauer, E.A.; Ky, B.; et al. Carfilzomib-Associated Cardiovascular Adverse Events: A Systematic Review and Meta-analysis. JAMA Oncol. 2018, 4, e174519. [CrossRef] [PubMed]

139. Camargo, M.; Farouk, S.; Campbell, K. Help or hindrance? An atypical presentation of Carfilzomib-induced nephrotoxicity. In Proceedings of the 19th International Conference on Dialysis, Advances in CKD, Las Vegas, NV, USA, 1-3 February 2017.

140. Oprozomib. Available online: https://myelomaresearchnews.com/oprozomib/ (accessed on 8 May 2020).

141. Marizomib. Available online: https://myelomaresearchnews.com/marizomib/ (accessed on 8 May 2020).

142. Roth, P.; Reijneveld, J.C.; Gorlia, T.; Dhermain, F.; Vos, F.Y.F.L.D.; Vanlancker, M.; O'Callaghan, C.J.; Rhun, E.L.; Bent, M.J.V.D.; Mason, W.P.; et al. EORTC 1709/CCTG CE.8: A phase III trial of marizomib in combination with standard temozolomide-based radiochemotherapy versus standard temozolomide-based radiochemotherapy alone in patients with newly diagnosed glioblastoma. J. Clin. Oncol. 2019, 37, TPS2072. [CrossRef]

143. Cvek, B.; Dvorak, Z. The value of proteasome inhibition in cancer: Can the old drug, disulfiram, have a bright new future as a novel proteasome inhibitor? Drug Discov. Today 2008, 13, 716-722.

144. Ekinci, E.; Rohondia, S.; Khan, R.; Dou, Q.P. Repurposing Disulfiram as An Anti-Cancer Agent: Updated Review on Literature and Patents. Recent Pat. Anti-Canc. 2019, 14, 113-132.

145. Cunha, J.P. Antabuse side effects center. Available online: https://www.rxlist.com/antabuse-side-effectsdrug-center.htm\#overview (accessed on 2 July 2020).

146. Field-Smith, A.; Morgan, G.J.; Davies, F.E. Bortezomib (Velcadetrade mark) in the treatment of multiple myeloma. Ther. Clin. Risk Manag. 2006, 2, 271-279. [CrossRef]

147. Cunha, J.P. Ninlaro side effects center. Available online: https://www.rxlist.com/ninlaro-side-effects-drugcenter.htm (accessed on 2 July 2020).

148. Siegel, D.S. From clinical trials to clinical practice: Single-agent carfilzomib adverse events and their management in patients with relapsed and/or refractory multiple myeloma. Ther. Adv. Hematol. 2013, 4, 354-365. [CrossRef]

149. McBride, L.; Samuel, C.O. The side effect profile of Carfilzomib: From clinical trials to clinical practice. J. Adv. Pract. Oncol. 2013, 4, 22-30.

150. Potts, B.C.; Albitar, M.X.; Anderson, K.C.; Baritaki, S.; Berkers, C.; Bonavida, B.; Chandra, J.; Chauhan, D.; Cusack, J.C., Jr.; Fenical, W.; et al. Marizomib, a proteasome inhibitor for all seasons: Preclinical profile and a framework for clinical trials. Curr. Cancer Drug Targets 2011, 11, 254-284. [CrossRef] [PubMed]

151. Rajan, A.M.; Kumar, S. New investigational drugs with single-agent activity in multiple myeloma. Blood Cancer J. 2016, 6, e451. [CrossRef]

152. Baker, C. Results from a phase I study of VLX1570 for patients with relapsed/refractory multiple myeloma. Available online: https://multiplemyelomahub.com/medical-information/results-from-a-phase-i-study-ofvlx1570-for-patients-with-relapsedrefractory-multiple-myeloma (accessed on 2 July 2020).

153. Swords, R.T.; Watts, J.; Erba, H.P.; Altman, J.K.; Maris, M.; Anwer, F.; Hua, Z.; Stein, H.; Faessel, H.; Sedarati, F.; et al. Expanded safety analysis of pevonedistat, a first-in-class NEDD8-activating enzyme inhibitor, in patients with acute myeloid leukemia and myelodysplastic syndromes. Blood Cancer J. 2017, 7, e520. [CrossRef] [PubMed]

154. Soucy, T.A.; Dick, L.R.; Smith, P.G.; Milhollen, M.A.; Brownell, J.E. The NEDD8 Conjugation Pathway and Its Relevance in Cancer Biology and Therapy. Genes Cancer 2010, 1, 708-716. [CrossRef]

155. Zhou, L.; Jiang, Y.; Luo, Q.; Li, L.; Jia, L. Neddylation: A novel modulator of the tumor microenvironment. Mol. Cancer 2019, 18,77-87. [CrossRef]

156. Pevonedistat (TAK-924): A Potential New Treatment for HR-MDS and AML. Available online: https://www.takeda.com/siteassets/system/investors/report/quarterlyannouncements/fy2019/4_ tak924_20191114.pdf (accessed on 9 May 2020).

157. LianLiang, P.; Zhang, H.; Wang, G.; Li, S.; Cong, S.; Luo, Y.; Zhang., B. KPNB1, XPO7 and IPO8 mediate the translocation of NF-kB/p65 into the nucleus. Traffic 2013, 14, 1132-1143.

158. Fagerlund, R.; Kinnunen, L.; Kohler, M.; Julkunen, I.; Melen, K. NF-\{kappa\} B is transported into the nucleus by importin \{alpha\}3 and importin \{alpha\}4. J. Biol. Chem. 2005, 280, 15942-15951. [CrossRef] 
159. Giridharan, S.; Srinivasan, M. Mechanisms of NF-кB p65 and strategies for therapeutic manipulation. J. Inflamm. Res. 2018, 11, 407-419. [CrossRef]

160. Viatour, P.; Merville, M.P.; Bours, V.; Chariot, A. Phosphorylation of NF-kappaB and IkappaB proteins: Implications in cancer and inflammation. Trends Biochem. Sci. 2005, 30, 43-52. [CrossRef]

161. Huang, B.; Yang, X.D.; Lamb, A.; Chen, L.F. Posttranslational modifications of NF-kappaB: Another layer of regulation for NF-kappaB signaling pathway. Cell Signal 2010, 22, 1282-1290. [CrossRef] [PubMed]

162. Kim, J.W.; Jang, S.M.; Kim, C.H.; An, J.H.; Kang, E.J.; Choi, K.H. New molecular bridge between RelA/p65 and NF- $\mathrm{BB}$ target genes via histone acetyltransferase TIP60 cofactor. J. Biol. Chem. 2012, 7780-91, 287. [CrossRef] [PubMed]

163. Kiernan, R.; Bres, V.; Ng, R.W.; Coudart, M.P.; El Messaoudi, S.; Sardet, C.; Jin, D.Y.; Emiliani, S.; Benkirane, M. Post-activation turn-off of NF-kappa B-dependent transcription is regulated by acetylation of p65. J. Biol. Chem. 2003, 278, 2758-2766. [CrossRef] [PubMed]

164. Hajmirza, A.; Emadali, A.; Gauthier, A.; Casasnovas, O.; Gressin, R.; Callanan, M.B. BET family protein BRD4: An emerging actor in NFKB signaling in inflammation and cancer. Biomedicines 2018, 6, 16. [CrossRef]

165. Mathew, C.; Ghildyal, R. CRM1 inhibitors for antiviral therapy. Front. Microbiol. 2017, 8. [CrossRef]

166. Ossareh-Nazari, B.; Bachelerie, F.; Dargemont, C. Evidence for a role of CRM1 in signal-mediated nuclear protein export. Science 1997, 278, 141-144. [CrossRef]

167. Wolff, B.; Sangher, J.-J.; Wang, A.Y. Leptomycin B is an inhibitor of nuclear export: Inhibition of nucleo-cytoplasmic translocation of the human immunodeficiency virus type 1 (HIV-l) Rev protein and Rev-dependent mRNA. Chem. Biol. 1997, 4, 139-147. [CrossRef]

168. Kosyna, F.K.; Depping, R. Controlling the gatekeeper: Therapeutic targeting of nuclear transport. Cells 2018, 7, 221. [CrossRef]

169. Sadowski, A.R.; Gardner, H.L.; Borgatti, A.; Wilson, H.; Vail, D.M.; Lachowicz, J.; Manley, C.; Turner, A.; Klein, M.K.; Waite, A.; et al. Phase II study of the oral selective inhibitor of nuclear export (SINE) KPT-335 (verdinexor) in dogs with lymphoma. BMC Vet. Res. 2018, 14, 1-7. [CrossRef]

170. Wang, A.Y.; Liu, H. The past, present, and future of CRM1/XPO1 inhibitors. Stem Cell Investig. 2019, 6, 6. [CrossRef]

171. Gavriatopoulou, M.; Chari, A.; Chen, C.; Bahlis, N.; Vogl, D.T.; Jakubowiak, A.; Dingli, D.; Cornell, R.F.; Hofmeister, C.C.; Siegel, D.; et al. Integrated safety profile of selinexor in multiple myeloma: Experience from 437 patients enrolled in clinical trials. Leukemia 2020. [CrossRef] [PubMed]

172. Karyopharm presents positive phase 1/2 Eltanexor data at the American Society of Hematology 2017 annual meeting. Available online: https://investors.karyopharm.com/news-releases/news-release-details/ karyopharm-presents-positive-phase-12-eltanexor-data-american (accessed on 2 July 2020).

173. Karyopharm Announces: FDA Considers the Effectiveness and Safety Technical Sections Complete to Support Conditional Approval for the New Animal Drug Application for Verdinexor (KPT-335) to Treat Lymphoma in Client Owned Dogs. Available online: https://investors.karyopharm.com/news-releases/newsrelease-details/karyopharm-announces-fda-considers-effectiveness-and-safety (accessed on 2 July 2020).

174. Bubna, A.K. Vorinostat-An Overview. Indian J. Dermatol. 2015, 60, 419. [CrossRef] [PubMed]

175. ISTODAX®(romidepsin) for Injection: Prescribing Information. Available online: https://www.accessdata. fda.gov/drugsatfda_docs/label/2009/022393lbl.pdf (accessed on 2 July 2020).

176. BELEODAQ®(Belinostat) for Injection, for Intravenous Administration: Prescribing Information. Available online: https://www.accessdata.fda.gov/drugsatfda_docs/label/2014/206256lbl.pdf (accessed on 2 July 2020).

177. Liu, J.D.; Sun, C.Y.; Tang, L.; Wu, Y.Y.; Wang, Q.Y.; Hu, B.; Hu, Y. Efficacy and safety of Panobinostat in relapsed or/and refractory multiple myeloma: Meta analyses of clinical trials and systematic review. Sci. Rep. 2016, 6, 27361. [CrossRef] [PubMed]

178. Zhang, Q.; Wang, T.; Geng, C.; Zhang, Y.; Zhang, J.; Ning, Z.; Jiang, Z. Exploratory clinical study of chidamide, an oral subtype-selective histone deacetylase inhibitor, in combination with exemestane in hormone receptor-positive advanced breast cancer. Chin. J. Cancer Res. 2018, 30, 605-612. [CrossRef]

179. Khan, C.; Pathe, N.; Fazal, S.; Lister, J.; Rossetti, J.M. Azacitidine in the management of patients with myelodysplastic syndromes. Ther. Adv. Hematol. 2012, 3, 355-373. [CrossRef] [PubMed]

180. Saba, H.I. Decitabine in the treatment of myelodysplastic syndromes. Ther. Clin. Risk Manag. 2007, 3, 807-817. [PubMed] 
181. Wagstaff, K.M.; Sivakumaran, H.; Heaton, S.M.; Harrich, D.; Jans, D.A. Ivermectin is a specific inhibitor of importin $\alpha / \beta$-mediated nuclear import able to inhibit replication of HIV-1 and dengue virus. Biochem. J. 2012, 443, 851-856. [CrossRef]

182. Soderholm, J.F.; Bird, S.L.; Kalab, P.; Sampathkumar, Y.; Hasegawa, K.; Uehara-Bingen, M.; Weis, K.; Heald, R. Importazole, a small molecule inhibitor of the Transport Receptor Importin- $\beta$. ACS Chem. Biol. 2011, 6, 700-708.

183. Lin, Y.-Z.; Yao, S.; Veach, R.A.; Torgerson, T.R.; Hawiger, J. Inhibition of nuclear translocation of transcription factor NF- $\mathrm{KB}$ by a synthetic peptide containing a cell membrane-permeable motif and nuclear localization sequence. J. Biol. Chem. 1995, 270, 14255-14258.

184. Wang, Y.F.; Xu, X.; Fan, X.; Zhang, C.; Wei, Q.; Wang, X.; Guo, W.; Xing, W.; Yu, J.; Yan, J.-L.; et al. A Cell-penetrating peptide suppresses inflammation by inhibiting NF-кB signaling. Mol. Ther. 2011, 19, 1849-1857.

185. O'Shea, J.M.; Perkins, N.D. Regulation of the RelA (p65) transactivation domain. Biochem. Soc. Trans. 2008, 36, 603-608. [CrossRef] [PubMed]

186. Chen, L.F.; Mu, Y.; Greene, W.C. Acetylation of RelA at discrete sites regulates distinct nuclear functions of NF-kappaB. EMBO J. 2002, 21, 6539-6548. [CrossRef] [PubMed]

187. Lecoq, L.; Raiola, L.; Chabot, P.R.; Cyr, N.; Arseneault, G.; Legault, P.; Omichinski, J.G. Structural characterization of interactions between transactivation domain 1 of the p65 subunit of NF-kappaB and transcription regulatory factors. Nucleic Acids Res. 2017, 45, 5564-5576. [CrossRef] [PubMed]

188. Rothgiesser, K.M.; Fey, M.; Hottiger, M.O. Acetylation of p65 at lysine 314 is important for late NF-kappaB-dependent gene expression. BMC Genom. 2010, 11, 22. [CrossRef]

189. Virág, D.; Dalmadi-Kiss, B.; Vékey, K.; Drahos, L.; Klebovich, I.; Antal, I.; Ludányi, K. Current trends in the analysis of post-translational modifications. Chromatographia 2020, 83, 1-10. [CrossRef]

190. Yuksel, M.; Okajima, K.; Uchiba, M.; Okabe, H. Gabexate mesilate, a synthetic protease inhibitor, inhibits lipopolysaccharide-induced tumor necrosis factor-alpha production by inhibiting activation of both nuclear factor-kappaB and activator protein-1 in human monocytes. J. Pharmacol. Exp. Ther. 2003, 305, 298-305. [CrossRef]

191. Hoffman, E.P.; Schwartz, B.D.; Mengle-Gaw, L.J.; Smith, E.C.; Castro, D.; Mah, J.K.; McDonald, C.M.; Kuntz, N.L.; Finkel, R.S.; Guglieri, M.; et al. Vamorolone trial in Duchenne muscular dystrophy shows dose-related improvement of muscle function. Neurology 2019, 93, e1312-e1323. [CrossRef]

192. Zimmermann, P.; Ziesenitz, V.C.; Curtis, N.; Ritz, N. The immunomodulatory effects of macrolides-A systematic review of the underlying mechanisms. Front. Immunol. 2018, 9, 302-315. [CrossRef]

193. Sugawara, A.; Shima, H.; Sueki, A.; Hirose, T.; Matsui, H.; Nakano, H.; Hanaki, H.; Akagawa, K.S.; Ōmura, S.; Sunazuka, T. Non-antibiotic 12-membered macrolides: Design, synthesis and biological evaluation in a cigarette-smoking model. J. Antibiot. (Tokyo) 2016, 69, 319-326. [CrossRef]

194. Niloo, K.; Ritesh, R.; Erika, G.; Gerald, M. Plant polyphenols as inhibitors of NF-кB induced cytokine production—a potential anti-inflammatory treatment for Alzheimer's disease? Front. Mol. Neurosci. 2015, $8,24-28$.

195. Shimizu, K.; Funamoto, M.; Sunagawa, Y.; Shimizu, S.; Katanasaka, Y.; Miyazaki, Y.; Wada, H.; Hasegawa, K.; Morimoto, T. Anti-inflammatory action of Curcumin and its use in the treatment of lifestyle-related diseases. Eur. Cardiol. 2019, 14, 117-122. [CrossRef] [PubMed]

196. Sharifi-Rad, M.; Pezzani, R.; Redaelli, M.; Zorzan, M.; Imran, M.; Ahmed Khalil, A.; Salehi, B.; Sharopov, F.; Cho, W.C.; Sharifi-Rad, J. Preclinical activities of Epigallocatechin gallate in signaling pathways in cancer. Molecules 2020, 25, 467. [CrossRef] [PubMed]

197. Xie, S.; Li, S.; Tian, J.; Li, F. Iguratimod as a new drug for rheumatoid arthritis: Current landscape. Front. Pharmacol. 2020, 11, 73-81. [CrossRef] [PubMed]

198. Li, G.; Yamasaki, R.; Fang, M.; Masaki, K.; Ochi, H.; Matsushita, T.; Kira, J.I. Novel disease-modifying anti-rheumatic drug iguratimod suppresses chronic experimental autoimmune encephalomyelitis by down-regulating activation of macrophages/microglia through an NF-kB pathway. Sci. Rep. 2018, 8, 1933-1948. [CrossRef] [PubMed]

199. Ehsanian, R.; Van Waes, C.; Feller, S.M. Beyond DNA binding-A review of the potential mechanisms mediating quinacrine's therapeutic activities in parasitic infections, inflammation, and cancers. Cell Commun. Signal 2011, 9, 13. [CrossRef] [PubMed] 
200. Martin, R.; Mrowietz, U.; Wiegrebe, W.; Jirovsky, D.; Loewe, R.; Pillinger, M.; Gröger, M.; Holnthoner, W.; Wolff, K.; Petzelbauer, P. Dimethylfumarate inhibits Tumor-Necrosis-Factor-induced CD62E expression in an NF-kB-dependent manner. J. Invest. Dermatol. 2001, 117, 1363-1368. [CrossRef]

201. Yan, B.; Kuick, C.H.; Lim, M.; Venkataraman, K.; Tennakoon, C.; Loh, E.; Lian, D.; Leong, M.Y.; Lakshmanan, M.; Tergaonkar, V.; et al. Platform comparison for evaluation of ALK protein immunohistochemical expression, genomic copy number and hotspot mutation status in neuroblastomas. PLOS ONE 2014, 9, e106575. [CrossRef]

202. Phase I/IIa Study of DTP3 in Patients with Advanced Multiple Myeloma. Available online: https://www.hra.nhs.uk/planning-and-improving-research/application-summaries/research-summaries/ phase-iiia-study-of-dtp3-in-patients-with-advanced-multiple-myeloma/ (accessed on 10 May 2020).

C 2020 by the authors. Licensee MDPI, Basel, Switzerland. This article is an open access article distributed under the terms and conditions of the Creative Commons Attribution (CC BY) license (http://creativecommons.org/licenses/by/4.0/). 